Prepared for the U.S. Department of Energy under Contract DE-AC05-76RL01830

\title{
Attributes of the Federal Energy Management Program's Federal Site Building Characteristics Database
}

SA Loper

WF Sandusky

December 2010

Pacific Northwest

NATIONAL LABORATORY

Proudly Operated by Battelle Since 1965 


\title{
DISCLAIMER
}

This documentation was prepared as an account of work sponsored by an agency of the United States Government. Neither the United States Government nor any agency thereof, nor Battelle Memorial Institute, nor any of their employees, makes any warranty, express or implied, or assumes any legal liability or responsibility for the accuracy, completeness, or usefulness of any information, apparatus, product, or process disclosed, or represents that its use would not infringe privately owned rights. Reference herein to any specific commercial product, process, or service by trade name, trademark, manufacturer, or otherwise does not necessarily constitute or imply its endorsement, recommendation, or favoring by the United States Government or any agency thereof, or Battelle Memorial Institute. The views and opinions of authors expressed herein do not necessarily state or reflect those of the United States Government or any agency thereof.

\author{
PACIFIC NORTHWEST NATIONAL LABORATORY \\ operated by \\ BATTELLE \\ for the \\ UNITED STATES DEPARTMENT OF ENERGY \\ under Contract DE-AC05-76RL01830
}

Printed in the United States of America

Available to DOE and DOE contractors from the Office of Scientific and Technical Information,

P.O. Box 62, Oak Ridge, TN 37831-0062;

ph: (865) 576-8401, fax: (865) 576-5728

email: reports@adonis.osti.gov

Available to the public from the National Technical Information Service,

U.S. Department of Commerce, 5285 Port Royal Rd., Springfield, VA 22161

ph: (800) 553-6847, fax: (703) 605-6900

email: orders@ntis.fedworld.gov

online ordering: http://www.ntis.gov/ordering.htm

This document was printed on recycled paper.

$(8 / 00)$ 
PNNL-20175

\section{Attributes of the Federal Energy Management Program's Federal Site Building Characteristics Database}

SA Loper

WF Sandusky

December 2010

Prepared for

Federal Energy Management Program

U.S. Department of Energy

under Contract DE-AC05-76RL01830

Pacific Northwest National Laboratory

Richland, Washington 99352 



\section{Executive Summary}

Typically, the Federal building stock is referred to as a group of about one-half million buildings throughout the United States. Additional information beyond this level is generally limited to distribution of that total by agency and maybe distribution of the total by state. However, additional characterization of the Federal building stock is required as the Federal sector seeks ways to implement efficiency projects to reduce energy and water use intensity as mandated by legislation and Executive Order. By using a Federal facility database that was assembled for use in a geographic information system tool, additional characterization of the Federal building stock is provided including information regarding the geographical distribution of sites, building counts and percentage of total by agency, distribution of sites and building totals by agency, distribution of building count and floor space by Federal building type classification by agency, and rank ordering of sites, buildings, and floor space by state. A case study is provided regarding how the building stock has changed for the Department of Energy from 2000 through 2008.

Results from this study are valuable as agencies implement tactical aspects of their strategic sustainability plans as it relates to achieving and hopefully exceeding energy and water reduction goals. For example, within the Department of Defense (DOD), the Army has nearly twice as many sites as the Air Force or Navy and has the largest number of buildings and total floor space. The Army, therefore, may be able to achieve a larger percentage of the goal depending on building types and geographic location. In terms of building type and total floor space within the DOD, the majority is associated with housing, so a specific group of energy efficiency and water conservation measures should be considered.

For the civilian agencies, the US Postal Service has the largest number of sites, but the Department of Interior has the largest number of buildings, while the General Services Administration has the most floor space. For the civilian agencies, the largest percentage of building type is also housing, but in terms of floor space, the office building type is the largest. Thus a unique set of efficiency measures would be implemented. In terms of distribution of sites, buildings, and floor space geographically, the state with the most in all these categories is California. This is important in terms of available state incentives that could be captured to reduce the overall cost of implementation. When considering the total database, the state with the second most number of sites, buildings, and total floor space is Texas, which is an open access state with little or no incentives available. States with the second largest number of civilian sites, buildings, and floor space are New York, Wyoming, and New York, respectively. Each of these states has unique conditions regarding electric rates and available incentives. Washington DC has the third largest amount of civilian Federal floor space. 


\section{Contents}

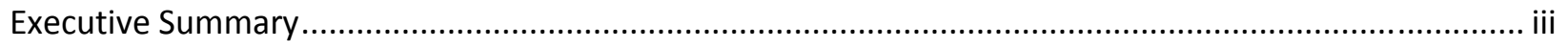

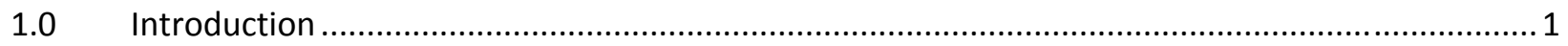

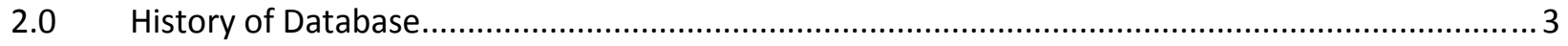

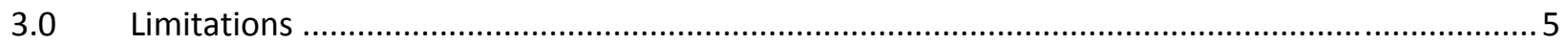

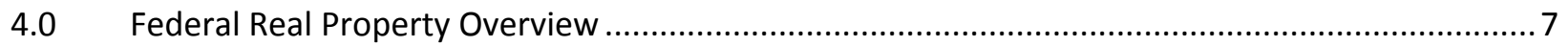

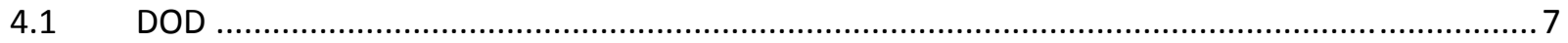

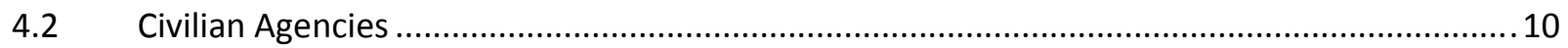

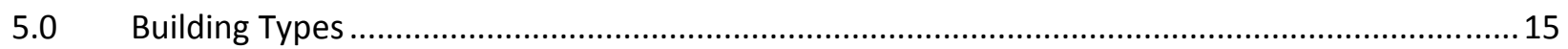

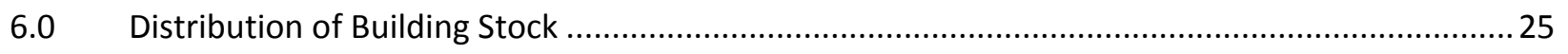

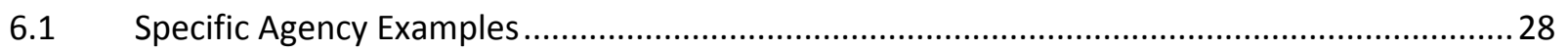

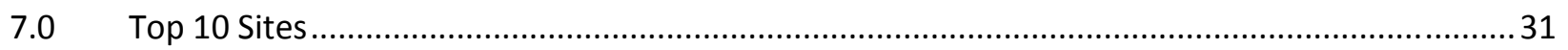

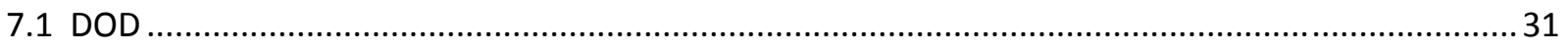

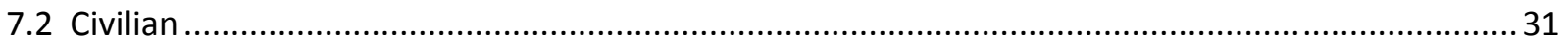

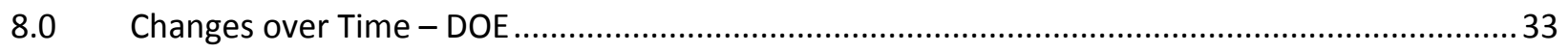

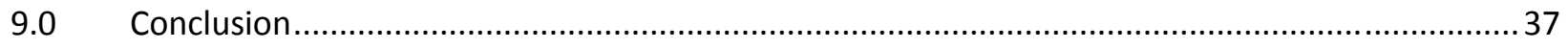

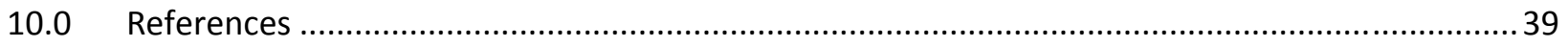




\section{Figures}

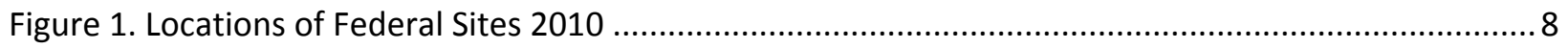

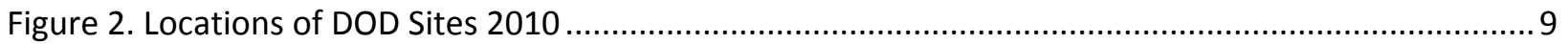

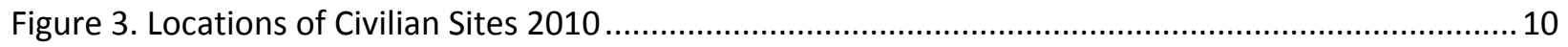

Figure 4. Top 15 Civilian Agencies by Total Building Count and Total Floor Space $\left(\mathrm{ft}^{2}\right)$........................13

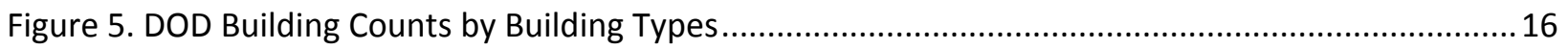

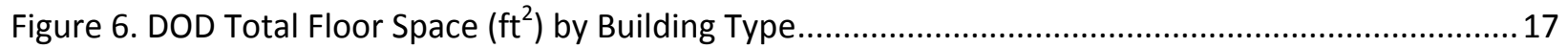

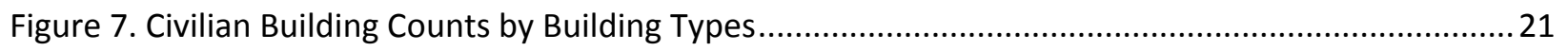

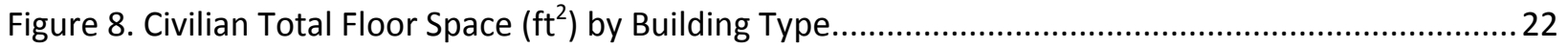

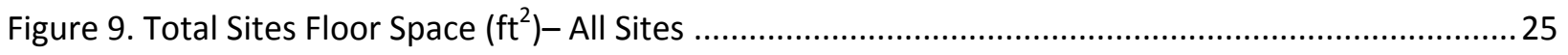

Figure 10. Changes in Total Building Counts by Building Types for DOE ............................................ 33

Figure 11. Changes in Total Floor Space $\left(\mathrm{ft}^{2}\right)$ by Building Types for DOE ........................................... 34 


\section{Tables}

Table 1. Summary of Total Federal Building Stock ................................................................................ 8

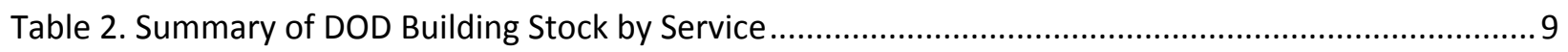

Table 3. Summary of Civilian Building Stock by Agency................................................................ 12

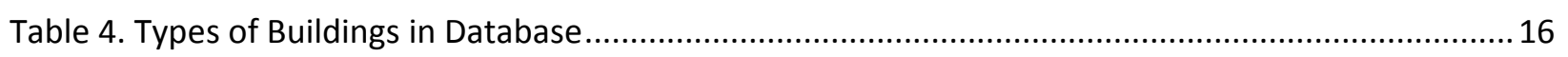

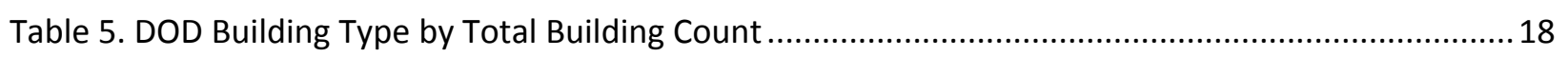

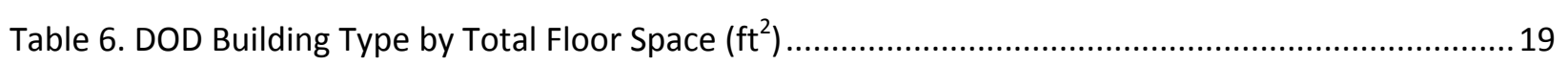

Table 7. Predominate Civilian Agencies for Building Count and Floor Space by Building Type.................20

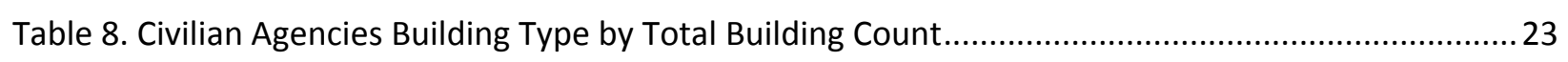

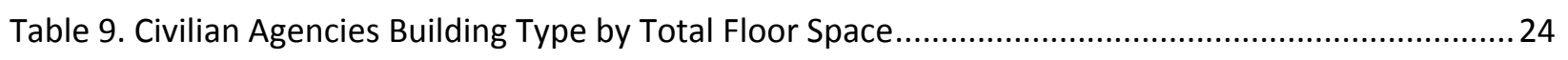

Table 10. Top Five States for Number of Sites, Buildings and Total Floor Space ...................................26

Table 11. DOD Service Top Five States for Number of Sites, Buildings and Total Floor Space..................27

Table 12. Civilian Agencies Top Five States for Number of Sites, Buildings and Total Floor Space............28

Table 13. Civilian Agencies and Sub-Agencies Top Five States for Number of Sites, Buildings and Total

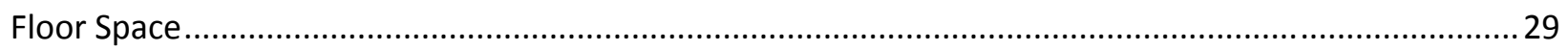

Table 14. Changes to DOE Building Stock by Building Type and Building Count .................................... 34

Table 15. Changes to DOE Building Stock by Building Type and Total Floor Space ................................. 35 


\subsection{Introduction}

The Federal sector continues to seek ways to reduce both energy and potable water intensity in the Federal building stock, as required by legislation (EISA 2007) and Executive Orders (72 FR 3919-3923 and 74 FR 52117-52127). Specific goals, on both an annual and cumulative basis, were established in both the legislation and Executive Orders. Additionally, agencies must report progress in meeting these goals on an annual basis. Both the annual and cumulative goals were established in terms of intensity reduction values (resource reduction per square foot) so knowledge of how an agency's floor space varies by building type and geographic region is useful in the development of effective and sound project implementation programs. These programs can then be adjusted over time to ensure a maximum level of impact for each agency.

Reducing the intensity value over time requires that actions must be taken to directly reduce or more efficiently use the available energy and potable water resource. The latter method is the preferred approach because it does not affect the ability of an agency to complete its assigned mission. This requires that efficiency opportunities be evaluated in terms of activities that can be implemented in association with the existing Federal building stock.

The Federal government manages a diverse real property inventory that is broken down into three asset categories: buildings, structures, and land. The structure category consists of such items as utility systems, road and bridges, parking structures, storage buildings, navigation and traffic aids, reclamation and irrigation, communication systems, airfield pavements, harbors and ports, museums, railroads, monuments and memorials. The vast majority of the efficiency opportunities will be associated with the buildings asset category. The most recent data (FY 2008) indicates there are 895,923 Federal buildings and structures, of which 407,062 are labeled as building assets with a combined total area of 3.29 billion square feet (FRPC 2009). Overall, these numbers can be considered stable given a reduction of less than $1 \%$ in the total number of assets and a $2 \%$ decrease in total areas, as compared to FY 2007 data. In terms of the building assets category, the change is larger with the total numbers of buildings being decreased by $8.8 \%$, as compared to the number reported in FY 2007 (FRPC 2009).

To better understand the potential efficiency opportunities, the U.S. Department of Energy's Federal Energy Management Program (FEMP) developed a database to provide information regarding building characteristics that can aid in locating energy and water efficiency opportunities. The database allows Federal agencies to identify potential projects that, once implemented, will increase the energy and water conservation of the sites, thus achieving mandated goals and saving taxpayer dollars. Information in the database includes the administrative agency, site names and addresses, building types, building counts, floor space in total square feet $\left(\mathrm{ft}^{2}\right)$ associated with each building type, energy data and source 
of data, if available. With this data, a better understanding of the Federal building stock can be determined to evaluate potential efficiency project opportunities.

Looking at a few components of the database is not enough to understand the characteristics of the Federal building stock. Annual real property reports are published by the Federal Real Property Council on other important aspects of the building stock such as disposition of real property, operating cost and various performance measures such as utilization and condition at the total Federal level or key agency level. When identifying efficiency potential, all aspects of the Federal building stock must be considered. For example, the United States Postal Service (USPS) has the most sites, a Marine Corp Base has the most buildings and an Army Base has the most total floor space. Therefore, to isolate one aspect does not provide a full, realistic picture of the Federal building stock.

This document provides information on the Federal building stock beyond generalizations, such as total floor space and number of buildings. It can assist agencies in making informed decisions in implementing actions related to their Strategic Sustainability plans and how those plans will evolve over time as projects are implemented and the nature of the Federal building stock changes over time. 


\subsection{History of Database}

The database is an integral part of a geographic information system (GIS) tool that was developed by the Pacific Northwest National Laboratory (PNNL) in 2000 as part of the on-going activities for FEMP as part of the Utility Service Program. Specific building characteristics data for Federal sites was provided by the General Services Administration (GSA), supplemented with agency specific data provided directly from agencies. Initially, the data was only accessible in ArcView 3.0, and the user had to purchase the software program to use the database. In 2002, the GIS tool was updated to ArcView 8.0, the latest version of the software available. In 2003, an Excel workbook was developed with predefined query tools, called Quicksort, so users did not have to purchase ArcView to use the data. Also, a web-based GIS tool was created soon after so users could have access the data on-line, as well as access to other spatial data, such as utility service area information, without having to purchase and install the software or acquire specific database information (http://fempgis.pnl.gov/).

In 2009, an effort was undertaken to determine how to improve the GIS tool. The first part of this effort was to reconcile and update the two different databases that existed for the Quicksort tool, an Excel file, and the GIS Web-based tool. Quicksort had data for 6,864 sites, while the web tool had 4,121 sites. It is uncertain why the two databases did not contain the same set of data. The database for both tools contained some data not found in the other, but the majority of the data was common between the two. The two datasets were combined into one called the Federal Site Building Characteristic Database (FSBCD). The data was reviewed to improve overall data quality (fixing missing address data, truncated text), and sites under 15,000 $\mathrm{ft}^{2}$, not previously included in the database, were added. Site data was updated as agencies provided new information. A request went out to every major agency asking for updated information. Agencies responding included GSA with data for 2007, United States Department of Agriculture- Agricultural Research Service (USDA-ARS) with data for 2009, and the Department of Interior (DOI) with data for 2008 and included sub-agency data for Bureau of Indian Affairs (DOI-BIA) and National Parks Service (DOI-NPS). Department of Energy (DOE) data was obtained directly from GSA's Federal Real Property Profile website for 2008.

Since the creation of the initial databases in 2000, the Department of Homeland Security (DHS) was created. However, for the FSBCD, the U.S. Coast Guard was retained as part of its original agency as of the year 2000 . 


\subsection{Limitations}

Although some agencies have provided updated building information over the years, most of the data is from FY 2000. Also, not every site has complete building characteristics information associated with it and only domestic sites with a few sites in Puerto Rico, Virgin Islands, Guam and American Samoa are included. A decision was made during the development of the FSBCD not to include smaller agencies (Smithsonian, Washington Headquarters Services, Broadcasting Board of Governors) and sites with unmanned buildings, such as substations and communication buildings because they offer minimal energy saving opportunities.

For some GSA, DOI, and DOI-BIA sites, only data for overall total building counts and total floor space were provided but were not broken down into building types (see Section 5.0 for definitions of building types). Therefore, this causes a discrepancy between total build counts and total floor space when compared to building type totals for building counts and floor space. This discrepancy caused total building count to be 525 greater than when looking at total building counts by building types (a variance of only 0.035 ) and total floor space is $14,246,968 \mathrm{ft}^{2}$ greater than when looking at total floor space by building types (a variance of only 0.005). 


\subsection{Federal Real Property Overview}

Currently, within the FSBCD, there are 14,861 Federal sites (Figure 1). A site does not necessarily mean one building; it can mean multiple buildings with multiple building types. These sites consist of a total of 409,494 buildings with almost 3 billion total $\mathrm{ft}^{2}$ of floor space (Table 1 ). The number of buildings per site range from 1 building to 5,410 buildings.

The Federal Real Property Council's FY 2008 Federal Real Property Report (FRPC 2009) states that the total Federal building asset is 407,062 and the total area of building assets is 3.29 billion $\mathrm{ft}^{2}$. These numbers include buildings located in the U.S., the District of Columbia, and U.S. Territories (America Samoa, Baker Island, Federated States of Micronesia, Guam, Howland Island, Jarvis Island, Midway Islands, Northern Mariana Islands, Republic of Palau, Puerto Rico, the U.S. Virgin Islands, Wake Island, and various Atolls).

The general overall characteristics of Department of Defense (DOD) and civilian sites are analyzed separately in Table 1. Even though DOD has fewer sites, they have a disproportionately greater number of buildings and total floor space, representing $67 \%$ of the total Federal floor space. DOD is made up of four departments (Services): Air Force, Army and Department of the Navy (which includes Marines). Information for the Army Corps of Engineers (ARCE) is broken out separately because they have different building characteristics than the Army. Civilian sites are made up of all other agencies excluding DOD and include 22 agencies. For the DOI, Department of Justice (DOJ), Department of Transportation (DOT), and USDA, data have been categorized into sub- agencies.

\subsection{DOD}

Of the 14,861 Federal sites, 2,588 are within DOD (Figure 2). These sites make up $17 \%$ of the total number of all Federal sites, but $78 \%$ of the total number of buildings and $67 \%$ of the total floor space (Table 1). DOD sites range from 1 to 5,410 buildings and from a few hundred square feet of floor space to over $26,000,000 \mathrm{ft}^{2}$.

Table 2 provides a breakdown of the DOD sites by Service. The Army has the largest number of sites (41\%), buildings (41\%) and total floor space (38\%). The Air Force is next with $20 \%$ of the sites, $29 \%$ of the buildings and $30 \%$ of the total floor space. The Navy has $21 \%$ of the sites, $27 \%$ of the buildings and $31 \%$ of the total floor space. The ARCE has $18 \%$ of the sites, $3 \%$ of the buildings and $1 \%$ of the total floor space. 


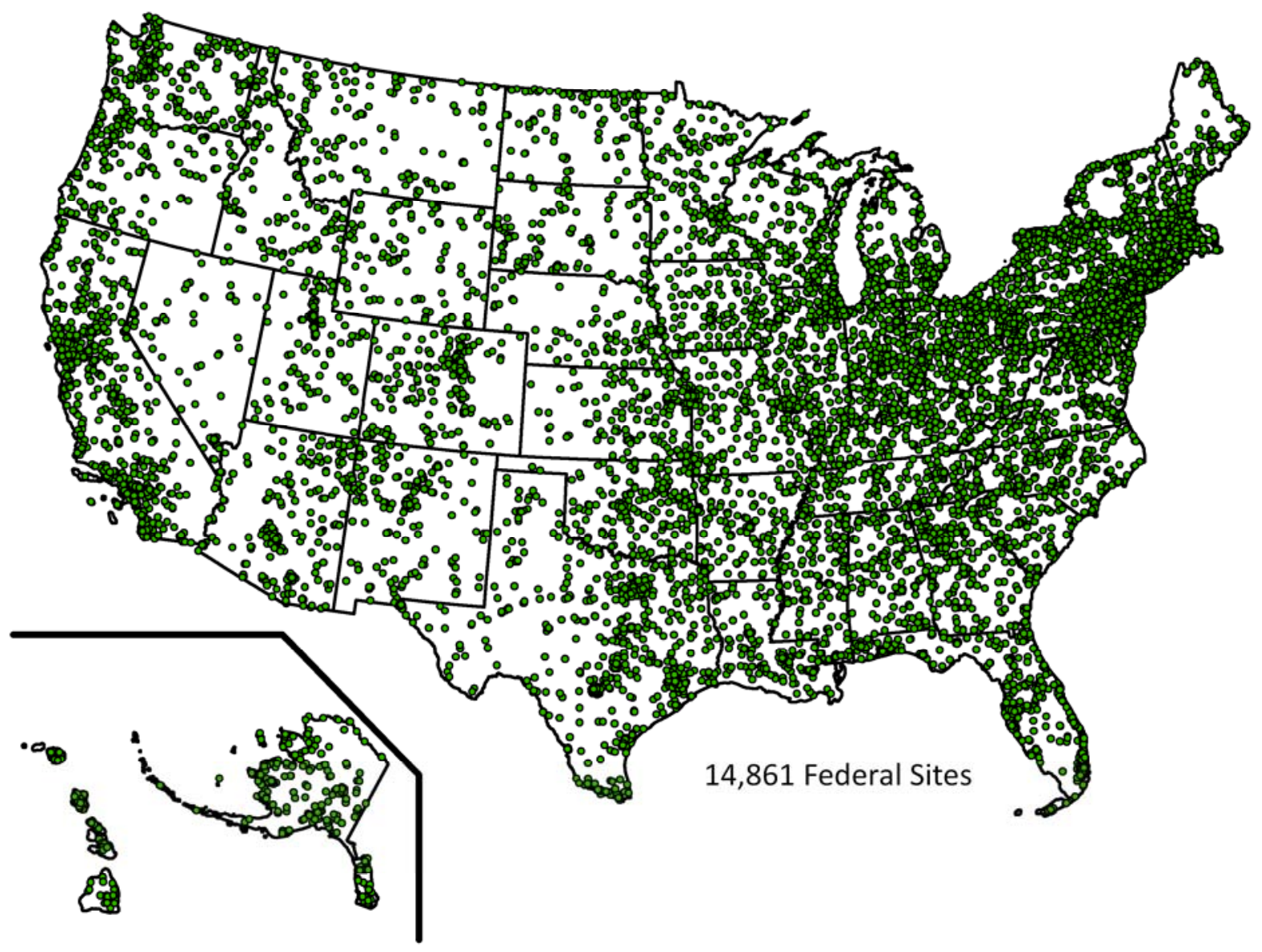

Figure 1. Locations of Federal Sites 2010

Table 1. Summary of Total Federal Building Stock

\begin{tabular}{lrrr}
\hline & \multicolumn{1}{c}{ DOD } & \multicolumn{1}{c}{ Civilian } & \multicolumn{1}{c}{ Total } \\
\hline Number of Sites/ (\%) & $2,588(17)$ & $12,273(83)$ & $\mathbf{1 4 , 8 6 1}$ \\
Number of Buildings/ (\%) & $318,090(78)$ & $91,404(22)$ & $\mathbf{4 0 9 , 4 9 4}$ \\
Total Floor Space $\left(\mathrm{ft}^{2}\right) /(\%)$ & $1,993,480,978(67)$ & $987,594,647(33)$ & $\mathbf{2 , 9 8 1 , 0 7 5 , 6 2 5}$ \\
\hline
\end{tabular}




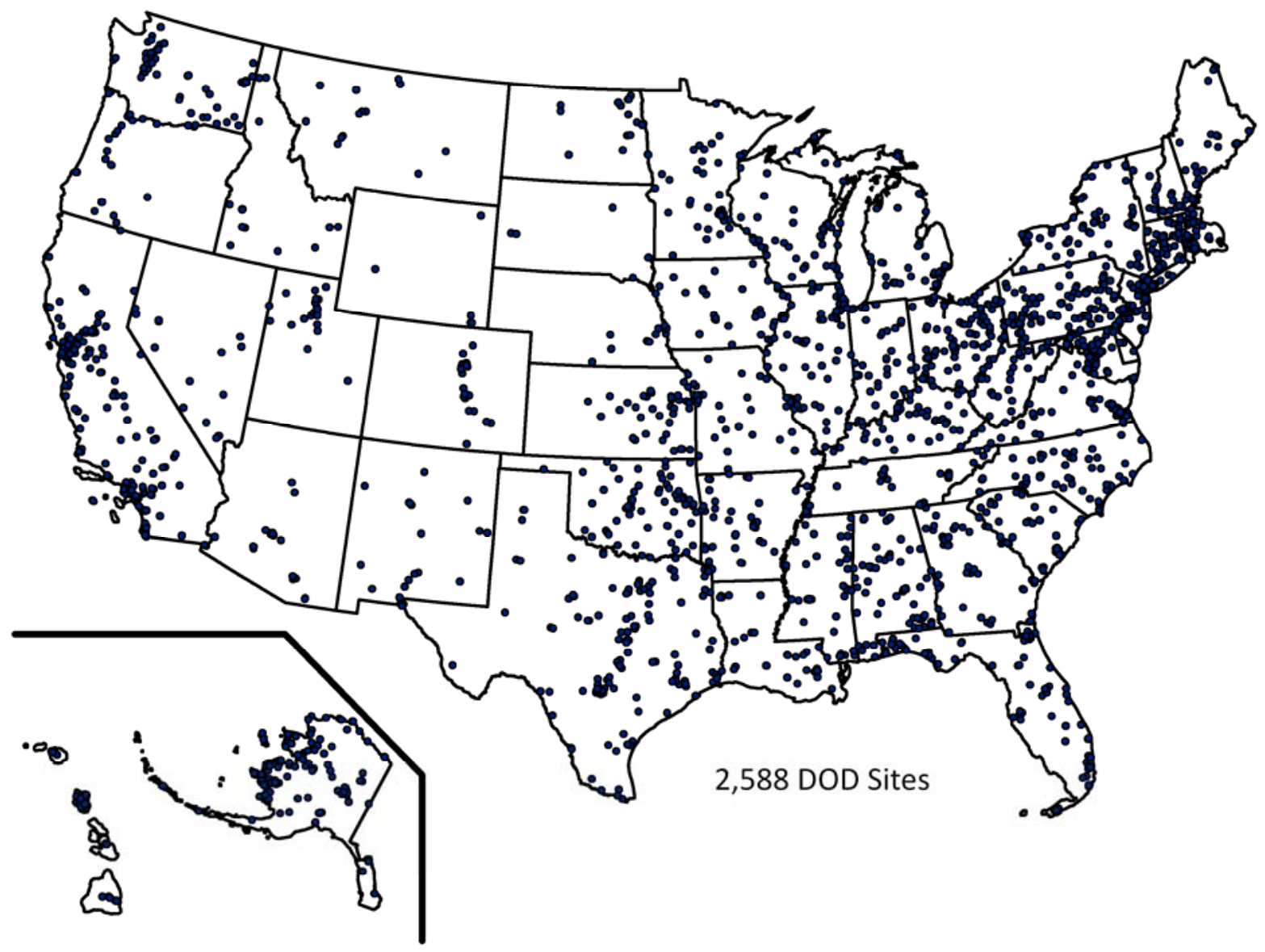

Figure 2. Locations of DOD Sites 2010

Table 2. Summary of DOD Building Stock by Service

\begin{tabular}{lrrr}
\hline \multicolumn{1}{c}{ DOD Agency } & \multicolumn{1}{c}{$\begin{array}{c}\text { Number of } \\
\text { Sites/ (\%) }\end{array}$} & $\begin{array}{c}\text { Number of } \\
\text { Buildings/ (\%) }\end{array}$ & \multicolumn{1}{c}{$\begin{array}{c}\text { Total Floor Space } \\
\left(\mathbf{f t}^{\mathbf{2}}\right) /(\mathbf{( \% )}\end{array}$} \\
\hline Air Force & $507(20)$ & $93,090(29)$ & $602,128,614(30)$ \\
Army & $1,075(41)$ & $130,885(41)$ & $767,998,297(38)$ \\
Army Corps of Engineers & $466(18)$ & $9,217(3)$ & $11,260,293(1)$ \\
Navy/Marines & $540(21)$ & $84,898(27)$ & $612,093,774(31)$ \\
\hline \hline TOTAL & $\mathbf{2 , 5 8 8}$ & $\mathbf{3 1 8 , 0 9 0}$ & $\mathbf{1 , 9 9 3 , 4 8 0 , 9 7 8}$ \\
\hline
\end{tabular}




\subsection{Civilian Agencies}

There are 12,273 sites that make up the civilian agency building stock (Table 1), which are geographically plotted in Figure 3 . These sites make up $83 \%$ of the total number of Federal sites but only $22 \%$ of the total number of buildings and $33 \%$ of the total floor space (Table 1). Civilian sites range from 1 to 3,863 buildings per site and from a few hundred square feet in floor space to over $12,000,000 \mathrm{ft}^{2}$.

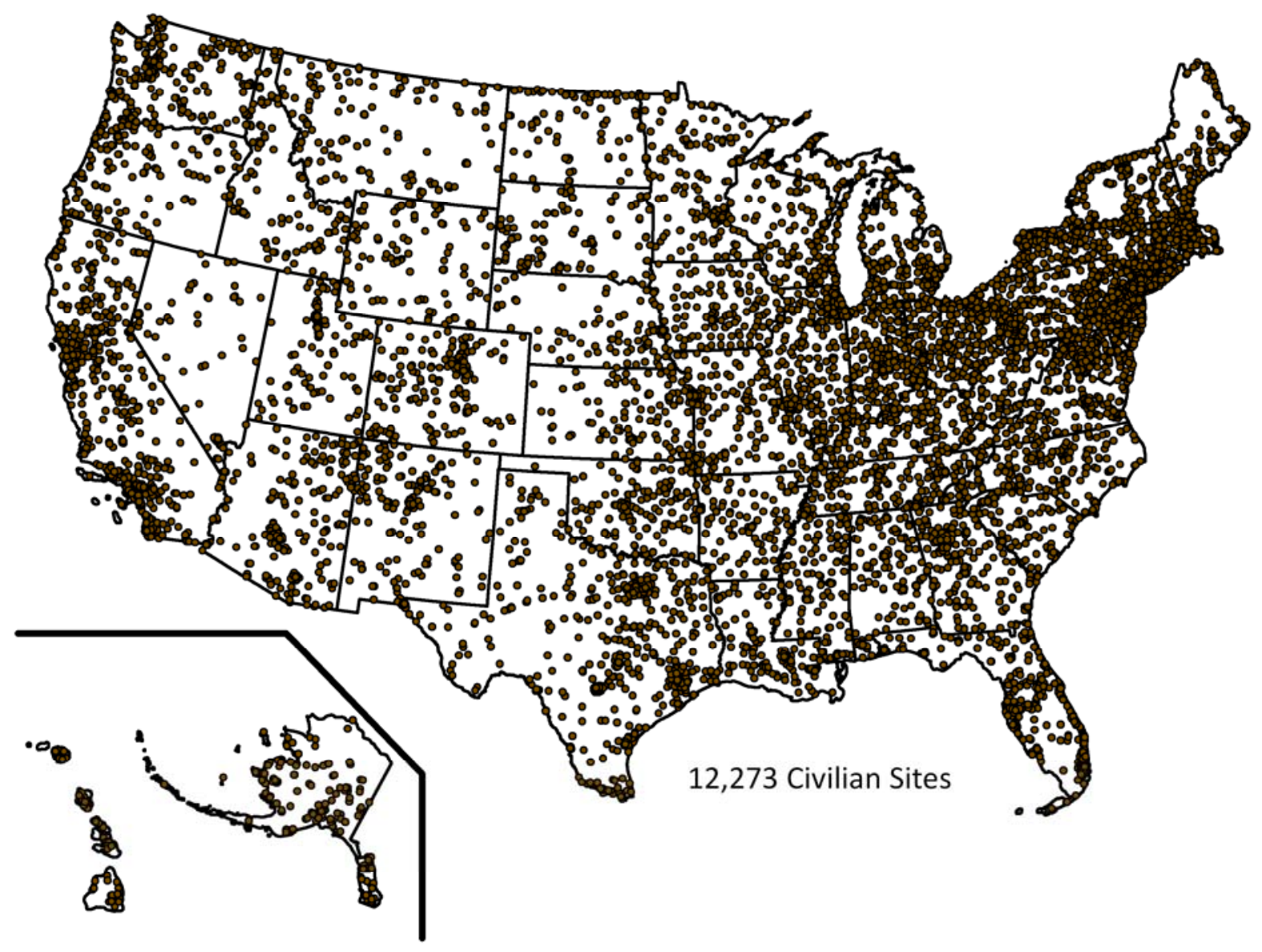

Figure 3. Locations of Civilian Sites 2010 
In the database, there are 22 civilian agencies and 6 sub-agencies. Agencies vary from having 1 site in the database (Government Printing Office) up to 5,704 sites for the USPS. In terms of number of buildings, the National Archives and Records Administration has only four buildings, while DOI has 23,830 buildings. In terms of total floor space, the Federal Communications Commission has just over $100,000 \mathrm{ft}^{2}$, while the GSA has $296,212,609 \mathrm{ft}^{2}$ of floor space (Table 3).

Figure 4 compares the top 15 Civilian agencies for total number of buildings and total floor space. DOI has the most buildings with 23,830 , but is $6^{\text {th }}$ in total floor space with $36,412,016 \mathrm{ft}^{2}$. GSA has the greatest total floor space at $296,212,609 \mathrm{ft}^{2}$, but ranks $12^{\text {th }}$ in total number of buildings with 2,554 . USDA-Forest Service (USDA-FS) is second in total building count with 16,593 , but $10^{\text {th }}$ in total floor space with $21,941,117 \mathrm{ft}^{2}$. DOI and USDA-FS by the nature of their mission activities tend to have lots of smaller buildings when compared to an agency like GSA, which has fewer total buildings, but with a larger amount of floor space due to the presence of larger office buildings. This is critical information as agencies develop their respective efficiency programs. 
Table 3. Summary of Civilian Building Stock by Agency

\begin{tabular}{|c|c|c|c|}
\hline Civilian Agency & $\begin{array}{l}\text { Number } \\
\text { of Sites }\end{array}$ & $\begin{array}{l}\text { Number of } \\
\text { Buildings }\end{array}$ & $\begin{array}{c}\text { Total } \\
\text { Floor Space } \\
\left(\mathrm{ft}^{2}\right)\end{array}$ \\
\hline Defense - Education & 41 & 124 & $5,142,912$ \\
\hline Dept. Homeland Security & 56 & 520 & $4,369,451$ \\
\hline Dept. of Commerce & 165 & 513 & $5,625,966$ \\
\hline Dept. of Energy & 134 & 9,184 & $116,794,299$ \\
\hline Dept. of Interior & 580 & 23,830 & $36,412,016$ \\
\hline Dept. of Interior -Bureau of Indian Affairs & 378 & 7,969 & $24,489,690$ \\
\hline Dept. of Interior - Fish \& Wildlife Service & 97 & 558 & $4,240,124$ \\
\hline Dept. of Justice & 139 & 616 & $7,891,447$ \\
\hline Dept. of Justice-Bureau of Prisons & 76 & 2,367 & $35,476,518$ \\
\hline Dept. of Labor & 54 & 1,167 & $9,894,828$ \\
\hline Dept. of Transportation & 460 & 2,759 & $14,021,874$ \\
\hline Dept. of Transportation -Federal Aviation Administration & 1,307 & 2,605 & $9,948,041$ \\
\hline Environmental Protection Agency & 17 & 125 & $2,644,475$ \\
\hline Federal Communications Commission & 13 & 65 & 103,219 \\
\hline Government Printing Office & 1 & 5 & $1,852,724$ \\
\hline General Services Administration & 1,490 & 2,554 & $296,212,609$ \\
\hline Health and Human Services & 177 & 2,702 & $22,674,609$ \\
\hline National Archives and Records Administration & 4 & 4 & $3,328,000$ \\
\hline National Aeronautics and Space Administration & 33 & 3,085 & $44,333,568$ \\
\hline National Science Foundation & 16 & 204 & 970,874 \\
\hline Dept. of State & 9 & 122 & 377,859 \\
\hline Dept. of Treasury & 7 & 9 & $2,730,463$ \\
\hline Tennessee Valley Authority & 51 & 440 & $3,050,503$ \\
\hline US Dept. of Agriculture & 42 & 324 & $1,571,883$ \\
\hline US Dept. of Agriculture -Agriculture Research Service & 130 & 2,674 & $12,778,304$ \\
\hline US Dept. of Agriculture -Forest Service & 799 & 16,593 & $21,941,117$ \\
\hline US Postal Service & 5,704 & 5,704 & $162,347,342$ \\
\hline Veterans Affairs (VA) & 293 & 4,582 & $136,369,932$ \\
\hline TOTAL & 12,273 & 91,404 & $987,594,647$ \\
\hline
\end{tabular}




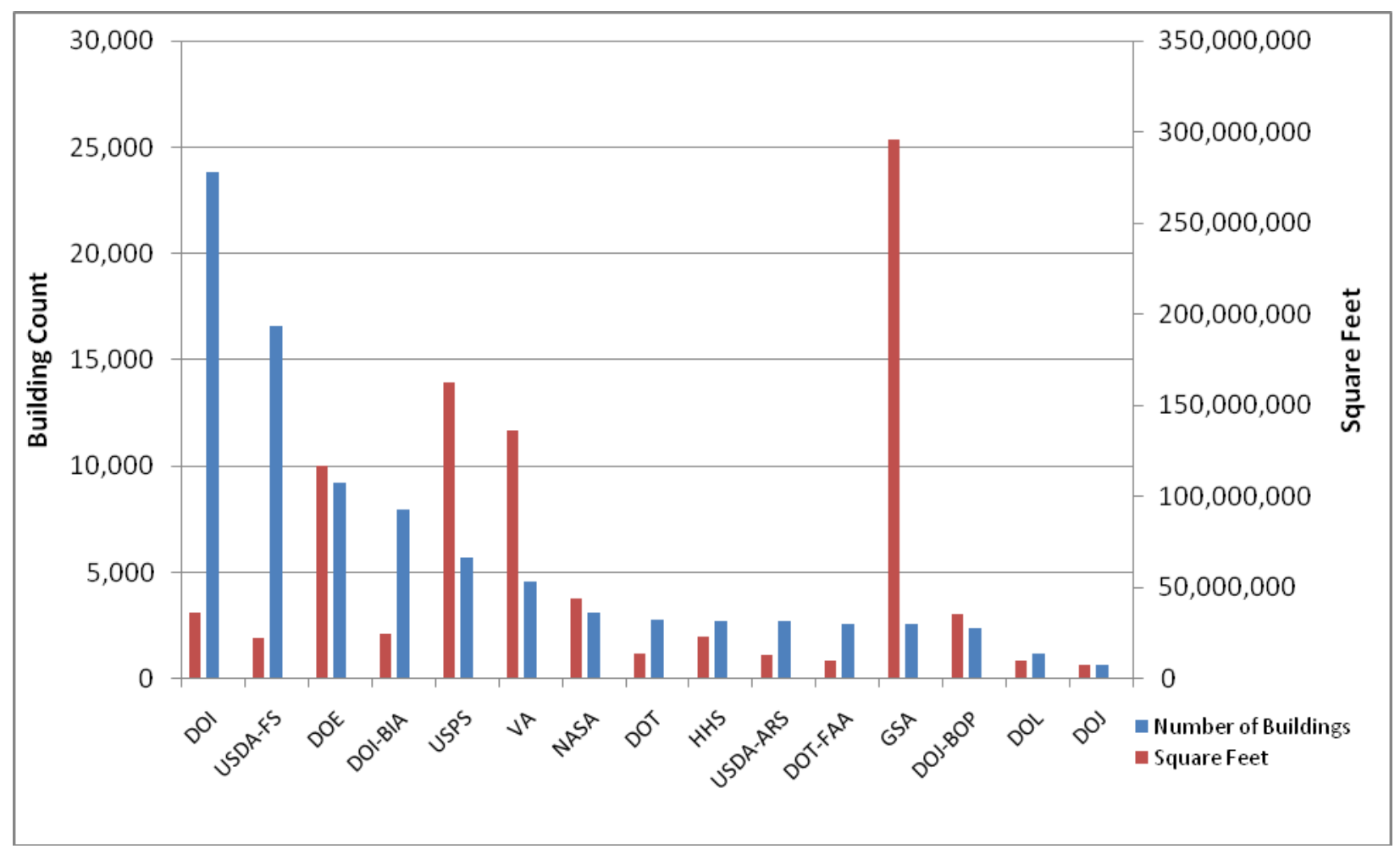

Figure 4. Top 15 Civilian Agencies by Total Building Count and Total Floor Space $\left(\mathrm{ft}^{2}\right)$ 


\subsection{Building Types}

There are 10 different building types within the database (Table 4). These building types follow GSA's real property database definitions of building categories (FRPC 2009). Comparing total building counts between agencies does not give enough information to thoroughly understand the characteristics of the building stock. Different agencies have different building needs. One agency may have only offices, where others agencies may have all building types. Only five DOD sites and no civilian sites have all types of buildings. But, when looking at Department of Justice-Bureau of Prisons (DOJ-BOP), prisons make up $82 \%$ of the building type and $97 \%$ of their total floor space. Only one other civilian agency, DOI-BIA, and 22 DOD sites have prisons.

By understanding the type of buildings in an agency's inventory, it can provide insight on energy and water savings potential because different building categories have distinct usage patterns. For example, prisons tend to have high potential for water efficiency improvements, while storage facilities typically have little potential for large efficiency enhancements. Prisons are extremely water intensive facilities because they operate 24 hours per day, seven days per week.

There are 6,954 DOD and civilian sites that only have office buildings types. USPS has 5,514 sites and GSA has 1,279 sites that only have office buildings. The remaining agencies each have less than 38 sites, with only office buildings. DOJ-BOP has no office building types.

For DOD, the housing building type makes up $45 \%$ of the total, followed by storage at $18 \%$, and service at $16 \%$ (Figure 5). For total floor space, housing building type makes up $31 \%$ of the total, followed by $22 \%$ for service and $18 \%$ for storage (Figure 6). When each DOD branch of service is compared in terms of building counts, housing is the top building type for Air Force, Army and Navy (Table 5). ARCE's top building type is other (see Table 4 for description of components within this category). In terms of total floor space, housing is the top building type for Army and Navy, but service is top for Air Force (Table 6). The Air Force and Army have all building types. The ARCE does not have any hospitals or prisons and very few schools and R\&D building types. The Navy does not have any prison building types listed in the database. 
Table 4. Types of Buildings in Database

\begin{tabular}{ll}
\hline Building Type & Explanation \\
\hline Hospital & In-patient healthcare facilities \\
Housing & Houses, dormitories, barracks \\
Industrial & Production or manufacturing \\
Office & Office space \\
Prison & Buildings for incarceration \\
& Not fitting into another category (Out- \\
& patient healthcare facilities, libraries, \\
chapels) & Laboratories \\
Other & Formal training \\
School & Service activities (Maintenance and \\
& repair) \\
Service & Warehouse used for storing goods \\
Storage &
\end{tabular}

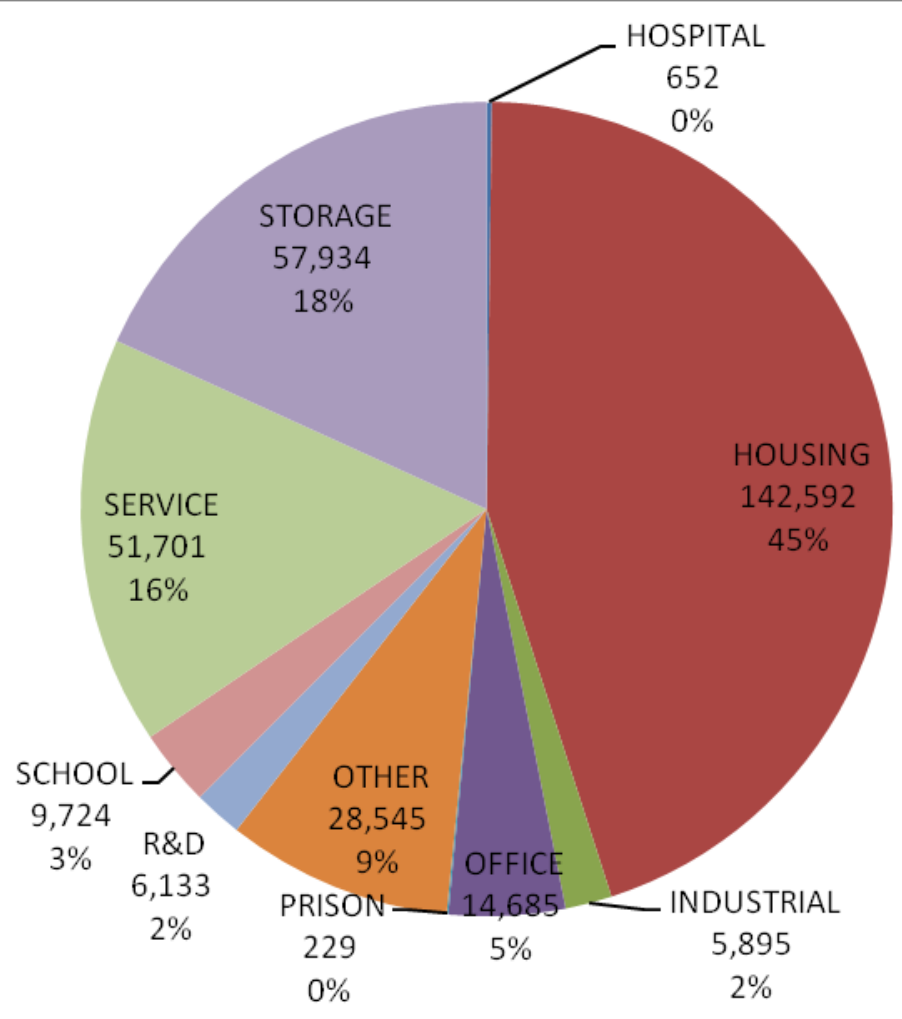

Figure 5. DOD Building Counts by Building Types 


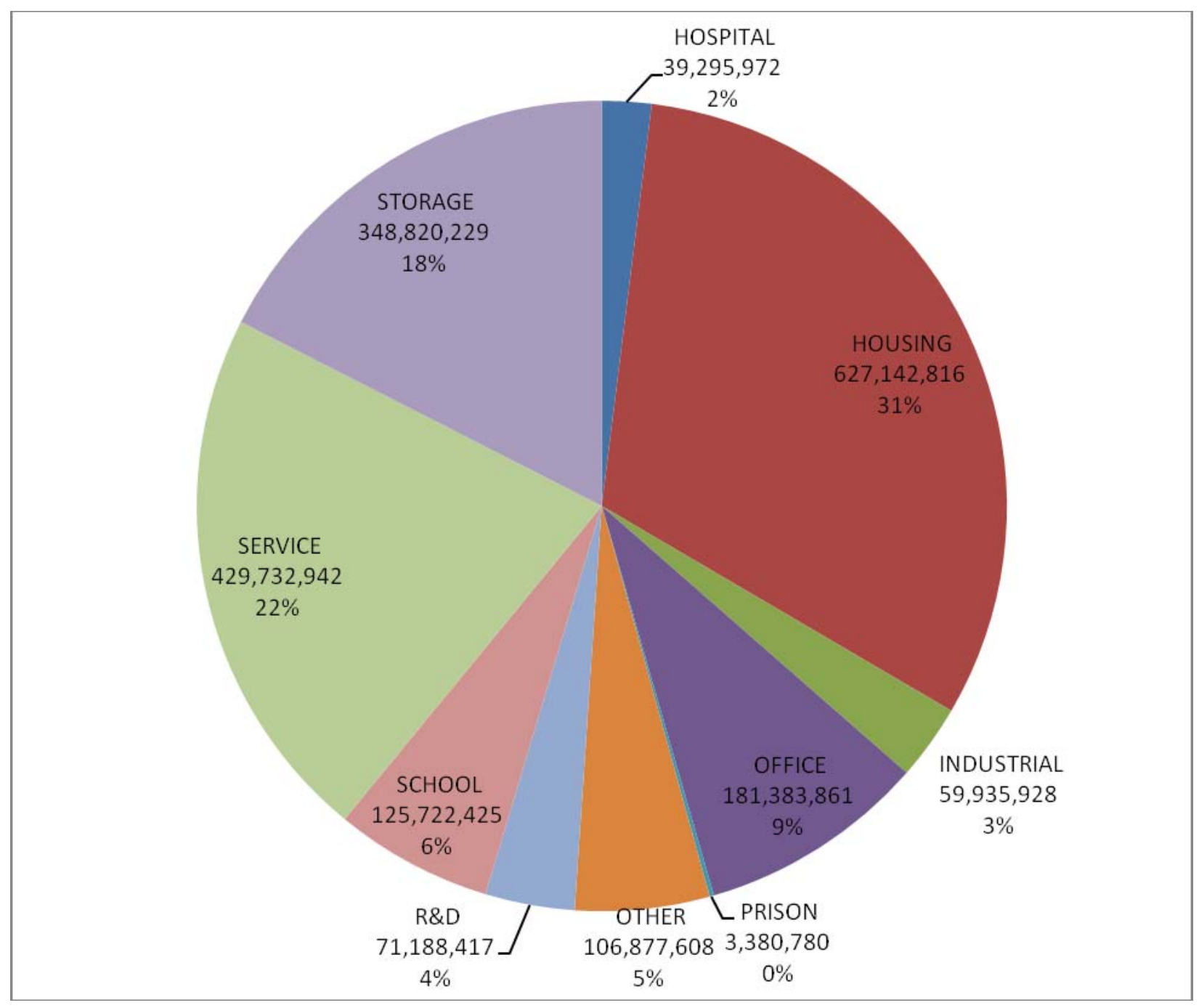

Figure 6. DOD Total Floor Space $\left(\mathrm{ft}^{2}\right)$ by Building Type 
Table 5. DOD Building Type by Total Building Count

\begin{tabular}{lrrrr}
\hline Building Type & Air Force & Army & ARCE & Navy \\
& & & & \\
\hline HOSPITAL & 338 & 180 & 0 & 134 \\
HOUSING & 50,034 & 44,002 & 328 & 48,228 \\
INDUSTRIAL & 197 & 4,944 & 40 & 714 \\
OFFICE & 2,484 & 8,737 & 485 & 2,979 \\
PRISON & 63 & 166 & 0 & 0 \\
OTHER & 5,077 & 10,976 & 5,652 & 6,840 \\
R\&D & 1,551 & 1,769 & 9 & 2,804 \\
SCHOOL & 2,286 & 5,363 & 1 & 2,074 \\
SERVICE & 16,669 & 17,488 & 1,054 & 16,490 \\
STORAGE & 14,391 & 37,260 & 1,648 & 4,635 \\
\hline \hline TOTAL & 93,090 & 130,885 & 9,217 & 84,898 \\
\hline
\end{tabular}


Table 6. DOD Building Type by Total Floor Space $\left(\mathrm{ft}^{2}\right)$

\begin{tabular}{lrrrr}
\hline Building Type & \multicolumn{1}{l}{ Air Force } & \multicolumn{1}{l}{ Army } & \multicolumn{1}{l}{ ARCE } & \multicolumn{1}{l}{ Navy } \\
\hline HOSPITAL & $14,126,181$ & $16,206,413$ & 0 & $8,963,378$ \\
HOUSING & $190,226,443$ & $234,620,413$ & 501,889 & $201,794,071$ \\
INDUSTRIAL & $14,949,830$ & $32,484,738$ & 98,617 & $12,402,743$ \\
OFFICE & $45,660,254$ & $83,977,997$ & $2,098,252$ & $49,647,358$ \\
PRISON & 407,993 & $2,972,787$ & 0 & \\
OTHER & $12,917,933$ & $66,764,465$ & $4,326,860$ & $22,868,350$ \\
R\&D & $26,248,257$ & $15,514,206$ & 47,636 & $29,378,318$ \\
SCHOOL & $35,359,794$ & $51,406,154$ & 748 & $38,955,729$ \\
SERVICE & $190,933,294$ & $83,848,624$ & $1,929,509$ & $153,021,515$ \\
STORAGE & $71,298,635$ & $180,202,500$ & $2,256,782$ & $95,062,312$ \\
\hline \hline TOTAL & $602,128,614$ & $767,998,297$ & $11,260,293$ & $612,093,774$ \\
\hline
\end{tabular}


For civilian agencies building counts, the housing building type makes up $22 \%$ of the total, followed by other at $21 \%$, storage at $19 \%$, and office at $15 \%$ (Figure 7 ). For total floor space, office building type makes up $47 \%$ of the total, followed by the hospital building type with $10 \%$, and $8 \%$ for both the storage and research and development building types (Figure 8).

The predominant civilian agencies by building type for building count and floor space is detailed in Table 7. Tables 8 and 9 show all civilian agencies by total building count and total floor space for each building type, respectively.

Table 7. Predominate Civilian Agencies for Building Count and Floor Space by Building Type

\begin{tabular}{lcc}
\hline Building Type & $\begin{array}{c}\text { Predominant } \\
\text { Agency by Building } \\
\text { Count }\end{array}$ & $\begin{array}{c}\text { Predominant Agency } \\
\text { by Building } \\
\text { Square Feet }\end{array}$ \\
\hline HOSPITAL & VA & VA \\
HOUSING & DOI & DOI-BIA \\
INDUSTRIAL & DOE & DOE \\
OFFICE & USPS & GSA \\
PRISON & DOJ-BOP & DOJ-BOP \\
OTHER & DOI & VA \\
R\&D & DOI & DOE \\
SCHOOL & DOI-BIA & DOI-BIA \\
SERVICE & DOI & DOE \\
STORAGE & USDA-FS & GSA \\
\hline \hline
\end{tabular}




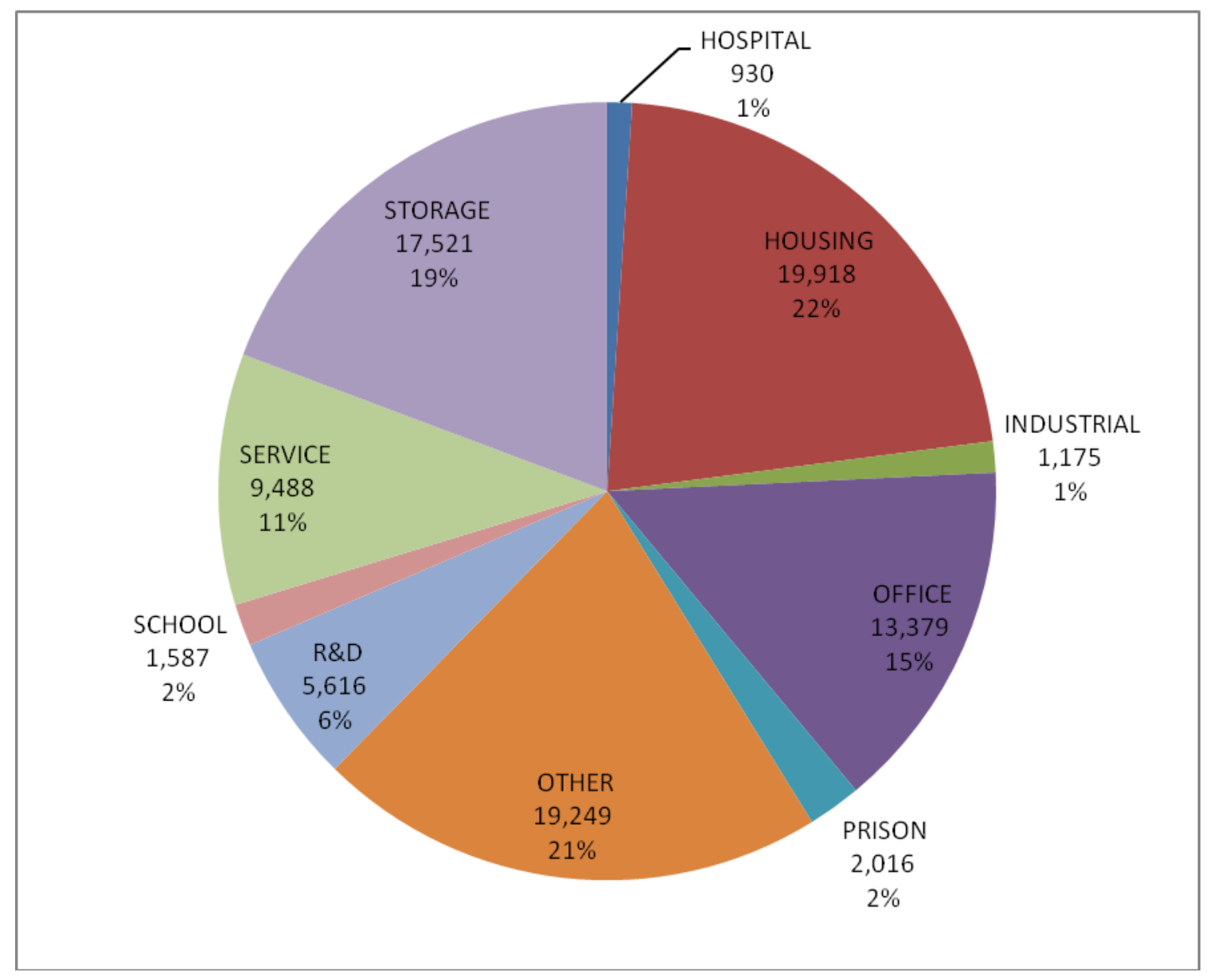

Figure 7. Civilian Building Counts by Building Types 


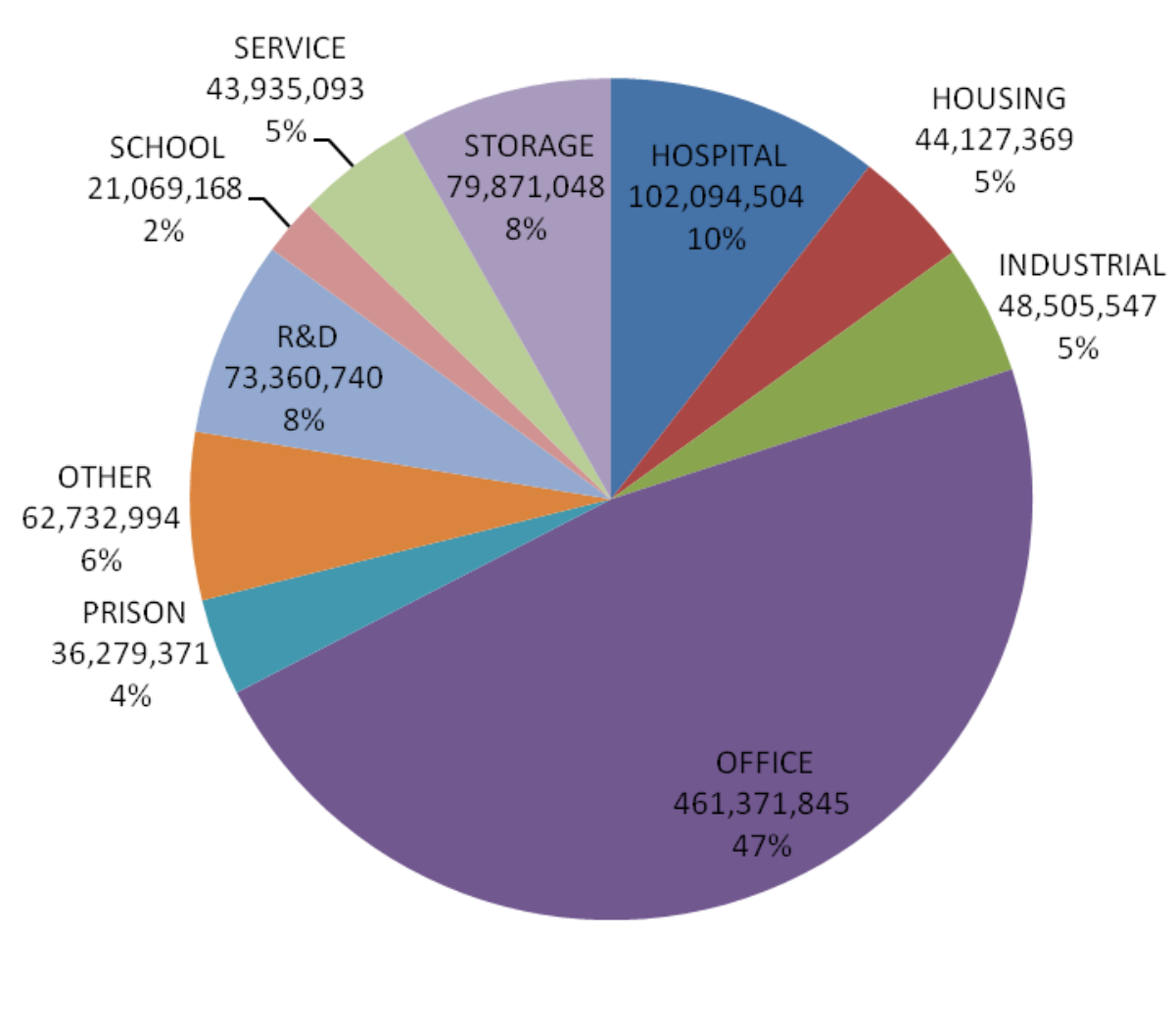

Figure 8. Civilian Total Floor Space $\left(\mathrm{ft}^{2}\right)$ by Building Type

There are 27 agencies/sub-agencies that have buildings classified as offices, 26 with building types classified as storage, 24 that have other and service, 22 that have housing, 19 that have R\&D, 16 that have industrial and schools, 9 that have hospitals and 3 that have prisons. In terms of building counts, the values can range from one building to over 8,340 for any specific building type. Total floor space for an agency building type can be less than $200 \mathrm{ft}^{2}$ (DOI-BIA R\&D) to $242,309,575 \mathrm{ft}^{2}$ (GSA buildings). 
Table 8. Civilian Agencies Building Type by Total Building Count

\begin{tabular}{|c|c|c|c|c|c|c|c|c|c|c|}
\hline & & & & & Buildir & g Count & & & & \\
\hline Agency & $\begin{array}{l}\mathbf{I} \\
\stackrel{0}{0} \\
\stackrel{D}{1} \\
\geq\end{array}$ & $\begin{array}{l}\text { I } \\
\text { O } \\
\frac{n}{2} \\
\Omega\end{array}$ & 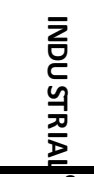 & $\begin{array}{l}\text { 유 } \\
\text { 끔 } \\
\text { m }\end{array}$ & $\begin{array}{l}\text { 끈 } \\
\text { 인 } \\
\text { 2 }\end{array}$ & $\begin{array}{l}\text { 엄 } \\
\text { 首 }\end{array}$ & $\begin{array}{l}\mathbb{X}_{0} \\
\square\end{array}$ & $\begin{array}{l}\text { ณ } \\
\text { 몽 }\end{array}$ & $\begin{array}{l}\text { 管 } \\
\text { 员 } \\
\text { 至 }\end{array}$ & 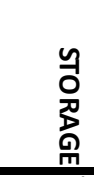 \\
\hline Defense - Education & 0 & 0 & 0 & 1 & 0 & 0 & 0 & 121 & 1 & 1 \\
\hline Dept. Homeland Security & 0 & 80 & 0 & 58 & 0 & 22 & 7 & 13 & 30 & 58 \\
\hline Dept. of Commerce & 0 & 71 & 0 & 76 & 0 & 25 & 336 & 0 & 0 & 5 \\
\hline Dept. of Energy & 24 & 181 & 731 & 1,745 & 0 & 374 & 1,407 & 126 & 2,319 & 2,277 \\
\hline Dept. of Interior & 3 & 6,026 & 92 & 740 & 0 & 8,340 & 1,857 & 44 & 3,032 & 3,539 \\
\hline Dept. of Interior -Bureau of Indian Affairs & 11 & 4,098 & 10 & 255 & 1 & 530 & 1 & 744 & 473 & 1,598 \\
\hline Dept. of Interior - Fish \& Wildlife Service & 0 & 119 & 55 & 49 & 0 & 114 & 18 & 13 & 94 & 96 \\
\hline Dept. of Justice & 0 & 100 & 106 & 116 & 79 & 60 & 0 & 0 & 34 & 121 \\
\hline Dept. of Justice-Bureau of Prisons & 0 & 431 & 0 & 0 & 1,936 & 0 & 0 & 0 & 0 & 0 \\
\hline Dept. of Labor & 17 & 212 & 0 & 103 & 0 & 235 & 0 & 287 & 71 & 242 \\
\hline Dept. of Transportation & 1 & 1,311 & 3 & 214 & 0 & 215 & 13 & 94 & 360 & 548 \\
\hline Dept. of Transportation -Federal Aviatio $n$ Adm inistration & 0 & 124 & 0 & 60 & 0 & 1,952 & 42 & 18 & 73 & 336 \\
\hline Environmental Protection Agency & 0 & 0 & 2 & 5 & 0 & 25 & 63 & 0 & 3 & 27 \\
\hline Fed eral Communications Commission & 0 & 0 & 0 & 2 & 0 & 46 & 2 & 0 & 3 & 12 \\
\hline Govemment Printing Office & 0 & 0 & 1 & 3 & 0 & 0 & 0 & 0 & 0 & 1 \\
\hline General Service Adminis tration & 0 & 19 & 2 & 1,618 & 0 & 93 & 1 & 4 & 95 & 602 \\
\hline Health and Human Services & 56 & 1,385 & 0 & 241 & 0 & 286 & 200 & 1 & 282 & 251 \\
\hline Nation al Archives and Records Administration & 0 & 0 & 0 & 1 & 0 & 3 & 0 & 0 & 0 & 0 \\
\hline Nation al Aeron autics and Space Adm in istration & 17 & 49 & 150 & 841 & 0 & 140 & 722 & 10 & 602 & 554 \\
\hline Nation al Science Foundation & 0 & 72 & 4 & 8 & 0 & 7 & 50 & 0 & 36 & 27 \\
\hline Dept. of State & 0 & 36 & 2 & 9 & 0 & 39 & 0 & 0 & 22 & 14 \\
\hline Dept. of Treasury & 0 & 49 & 5 & 33 & 0 & 57 & 0 & 81 & 9 & 27 \\
\hline Tennessee Valley Au tho rity & 0 & 8 & 0 & 5 & 0 & 112 & 10 & 0 & 77 & 228 \\
\hline US Dept. of Agriculture & 0 & 4 & 4 & 36 & 0 & 28 & 139 & 0 & 23 & 90 \\
\hline US Dept. of Agriculture -Agriculture Research Service & 0 & 85 & 0 & 114 & 0 & 1,131 & 406 & 0 & 237 & 701 \\
\hline US Dept. of Agriculture -Forest Service & 1 & 4,642 & 3 & 994 & 0 & 4,573 & 184 & 1 & 838 & 5,357 \\
\hline US Postal Service & 0 & 0 & 0 & 5,514 & 0 & 0 & 0 & 9 & 163 & 18 \\
\hline Veterans Affairs & 800 & 816 & 5 & 538 & 0 & 842 & 158 & 21 & 611 & 791 \\
\hline TOIAL & 930 & 19,918 & $1,1 / 5$ & $13,3 / 9$ & 2,016 & 19,249 & 5,616 & 1,581 & 9,488 & 17,521 \\
\hline
\end{tabular}


Table 9. Civilian Agencies Building Type by Total Floor Space

\begin{tabular}{|c|c|c|c|c|c|c|c|c|c|c|}
\hline \multirow[b]{2}{*}{ Agency } & \multicolumn{10}{|c|}{ Total Square Feet } \\
\hline & \begin{tabular}{l} 
D. \\
on \\
\multirow{2}{*}{} \\
\end{tabular} & 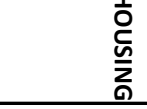 & 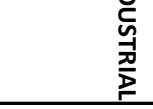 & $\begin{array}{l}\text { 유 } \\
\text { 竞 }\end{array}$ & 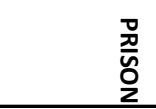 & $\begin{array}{l}\text { 엎 } \\
\text { 䘏 }\end{array}$ & $\begin{array}{l}D_{0}^{\circ} \\
0\end{array}$ & $\begin{array}{l}\text { 옴 } \\
\text { 임 }\end{array}$ & $\begin{array}{l}\text { 䈍 } \\
\text { 空 }\end{array}$ & 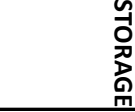 \\
\hline Defense - Education & 0 & 0 & 0 & 1,521 & 0 & 0 & 0 & $4,807,687$ & 333,288 & 416 \\
\hline Dept. Homeland Security & 0 & 307,916 & 0 & 136,381 & 0 & 184,230 & 278,757 & 143,648 & 114,064 & $332,63 \mathrm{C}$ \\
\hline Dept. of Commerce & 0 & 152,128 & 0 & $3,468,510$ & 0 & 81,211 & $1,895,169$ & 0 & 0 & 28,948 \\
\hline Dept. of Energy & 224,713 & 790,205 & $36,304,115$ & $23,890,176$ & 0 & $3,913,750$ & $29,950,564$ & $1,085,426$ & $9,477,561$ & $11,157,78 \mathrm{~s}$ \\
\hline Dept. of Interior & 22,592 & $8,045,327$ & 494,906 & $3,747,320$ & 0 & $12,068,858$ & $1,969,935$ & 437,919 & $4,680,648$ & $4,944,51$ \\
\hline Dept. of Interior -Bureau of Indian Affairs & 32,062 & $11,054,721$ & 23,177 & $1,018,052$ & 12,296 & $2,459,384$ & 196 & $6,477,378$ & $1,411,182$ & $2,001,242$ \\
\hline Dept. of Interior - Fish \& Wildlife Service & 0 & 346,667 & 703,199 & 639,450 & 0 & $1,127,146$ & 226,352 & 168,072 & 538,241 & 490,997 \\
\hline Dept. of Justice & 0 & 173,419 & $3,058,743$ & 475,611 & $1,898,655$ & $1,246,872$ & 0 & 0 & 102,904 & 935,243 \\
\hline Dept. of Justice-Bureau of Prisons & 0 & $1,108,098$ & 0 & 0 & $34,368,420$ & 0 & 0 & 0 & 0 & c \\
\hline Dept. of Labor & 167,754 & $2,588,181$ & 0 & 778,122 & 0 & $2,052,798$ & 0 & 3,371,954 & 149,771 & $786,24 \varepsilon$ \\
\hline Dept. of Transportation & 49,281 & $4,217,198$ & 150,716 & $2,697,203$ & 0 & $1,328,630$ & 726,400 & $1,299,888$ & $2,372,948$ & $1,179,61 \mathrm{C}$ \\
\hline Dept. of Transportation -Federal Aviation Administration & 0 & 210,463 & 0 & 746,983 & 0 & $6,534,492$ & 946,371 & 97,629 & 958,775 & $453,32 \varepsilon$ \\
\hline Environmental Protection Agency & 0 & 0 & 16,800 & 16,875 & 0 & 170,282 & $1,172,647$ & 0 & 3,870 & $1,264,001$ \\
\hline Federal Communications Commission & 0 & 0 & 0 & 5,420 & 0 & 48,379 & 23,250 & 0 & 2,404 & $23,76 \epsilon$ \\
\hline Government Printing Office & 0 & 0 & 159,253 & $1,306,748$ & 0 & 0 & 0 & 0 & 0 & 386,723 \\
\hline General Service Administration & 0 & 97,483 & 54,990 & $242,309,575$ & 0 & $4,454,866$ & 38,735 & 74,600 & $3,009,777$ & $31,925,615$ \\
\hline Health and Human Services & $6,082,924$ & $2,983,042$ & 0 & $2,597,447$ & 0 & $2,324,091$ & $6,186,111$ & 14,931 & $1,855,665$ & 630,398 \\
\hline National Archives and Records Administration & 0 & 0 & 0 & $1,375,000$ & 0 & $1,953,000$ & 0 & 0 & 0 & c \\
\hline National Aeronautics and Space Administration & 77,731 & 395,208 & $5,537,746$ & $9,509,249$ & 0 & 201,906 & $17,645,818$ & 222,312 & $5,966,554$ & $4,777,04$ \\
\hline National Science Foundation & 0 & 148,887 & 7,976 & 134,738 & 0 & 9,645 & 543,192 & 0 & 87,687 & $38,74 \mathrm{c}$ \\
\hline Dept. of State & 0 & 59,195 & 9,111 & 22,278 & 0 & 214,300 & 0 & 0 & 36,551 & 36,42 \\
\hline Dept. of Treasury & 0 & 569,695 & $1,802,215$ & $1,110,365$ & 0 & $1,203,919$ & 0 & 705,509 & 45,179 & 165,406 \\
\hline Tennessee Valley Authority & 0 & 10,207 & 0 & 310,598 & 0 & 166,279 & 20,166 & 0 & 278,192 & $2,265,06$ \\
\hline US Dept. of Agriculture & 0 & 9,848 & 76,405 & 76,361 & 0 & 412,741 & 737,582 & 0 & 95,352 & 163,59 \\
\hline US Dept. of Agriculture -Agriculture Research Service & 0 & 167,614 & 0 & 651,962 & 0 & $3,702,017$ & $6,027,877$ & 0 & 873,514 & $1,355,32$ \\
\hline US Dept. of Agriculture -Forest Service & 2,200 & $6,064,932$ & 10,428 & $3,047,816$ & 0 & $2,513,804$ & $1,345,251$ & 1,160 & $1,780,407$ & $7,175,11 \mathrm{c}$ \\
\hline US Postal Service & 0 & 0 & 0 & $153,829,512$ & 0 & 0 & 0 & $1,422,092$ & $5,234,834$ & $1,860,90$ \\
\hline Veterans Affairs & $95,435,247$ & 4,626,935 & 95,767 & $7,468,572$ & 0 & $14,360,394$ & $3,626,367$ & 738,963 & $4,525,725$ & $5,491,962$ \\
\hline TOTAL & $102,094,504$ & $44,127,369$ & $48,505,547$ & $461,371,845$ & $36,279,371$ & $62,732,994$ & $73,360,740$ & $21,069,168$ & $43,935,093$ & $79,871,04 \varepsilon$ \\
\hline
\end{tabular}




\subsection{Distribution of Building Stock}

Using average floor space size for a specific building type is not effective in the ultimate design of energy and water efficiency programs since the size of the individual buildings vary markedly across the Federal building stock. For example, there are 552 sites with greater than 1 million $\mathrm{ft}^{2}$ of floor space with five over 20 million $\mathrm{ft}^{2}$ (Figure 9). There are 1,728 sites between 100,000 and 999,999 $\mathrm{ft}^{2}$ of floor space, 2,594 sites between 25,000 and 99,999 $\mathrm{ft}^{2}$, and 9,987 buildings less than $25,000 \mathrm{ft}^{2}$ (Figure 9).

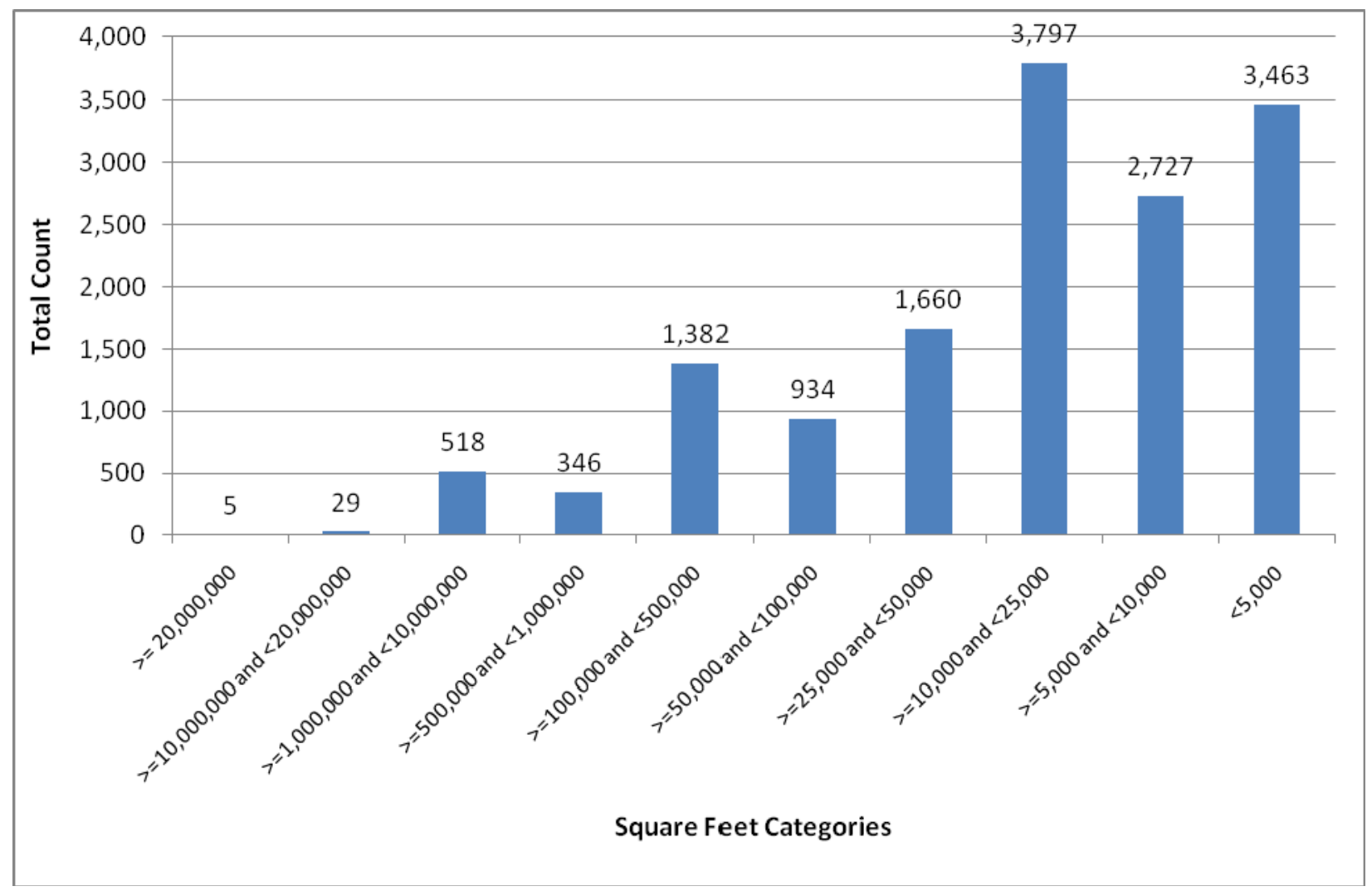

Figure 9. Total Sites Floor Space $\left(\mathrm{ft}^{2}\right)$ - All Sites

In terms of geographic location, California is the predominant state of Federal sites (8\%), number of buildings (15\%), and total floor space (14\%) (Table 10). Texas is second in all three categories; sites (6\%), buildings (7\%), floor space (7\%). Washington DC is ranked $45^{\text {th }}$ in number of sites and number of buildings, but $12^{\text {th }}$ in total floor space indicating a predominate number of larger Federal buildings. The states of Rhode Island, Delaware, New Hampshire, and Vermont have the lowest number of sites, buildings and total floor space. 
Table 10. Top Five States for Number of Sites, Buildings and Total Floor Space

\begin{tabular}{lclll}
\hline & Rank & \multicolumn{1}{c}{ All } & \multicolumn{1}{c}{ DOD } & \multicolumn{1}{c}{ Civilian } \\
\hline Sites & 1 & California & California & California \\
& 2 & Texas & Texas & New York \\
& 3 & New York & Pennsylvania & Texas \\
& 4 & Pennsylvania & Alaska & Pennsylvania \\
& 5 & Illinois & Florida & Illinois \\
\hline Buildings & 1 & California & California & California \\
& 2 & Texas & Texas & Wyoming \\
& 3 & Virginia & North Carolina & Arizona \\
& 4 & North Carolina & Virginia & New Mexico \\
& 5 & Hawaii & Hawaii & Texas \\
\hline Floor Space & 1 & California & California & California \\
& 2 & Texas & Texas & New York \\
& 3 & Virginia & Virginia & Washington DC \\
& 4 & Maryland & Georgia & Texas \\
& 5 & Georgia & Florida & Maryland \\
\hline
\end{tabular}

For each state, land area by square miles was obtained (Drexel University 2009) so that density per square mile for number of Federal sites, number of buildings, and total floor space could be determined. Per square mile, Washington DC has the most sites (2.23), the greatest number of buildings (32.5) and greatest total floor space $\left(1,317,297 \mathrm{ft}^{2}\right)$. Rhode Island, New Jersey, Massachusetts and Maryland are in the top five for the most sites per square mile. Hawaii, Rhode Island, New Jersey, and Maryland are in the top five for the greatest number of buildings and greatest total floor space per square mile.

For DOD sites only, California has the most sites (8\%), number of buildings (16\%) and total floor space (16\%) (Table 10). Texas is second with $6 \%$ of the sites, $7 \%$ of the total buildings, and $8 \%$ total floor space. Vermont, New Hampshire, and Wyoming have the lowest number of DOD sites.

In terms of the branches of services with DOD, California has the most sites (10\%), number of buildings (16\%) and total floor space (13\%) for Air Force sites (Table 11). California also has the most sites (18\%), number of buildings (32\%) and total floor space (32\%) for the Navy. Alaska has the most Army sites (7\%), but Texas has the most Army buildings (10\%) and total floor space (9\%).

For the civilian agencies, California has the largest number of sites (7\%), number of buildings (11\%) and total floor space (10\%) (Table 10). The state of Wyoming has the second largest number of buildings $(6 \%)$, but ranks $36^{\text {th }}$ for number of sites and $39^{\text {th }}$ for total floor space. This is because of DOI's Yellowstone and Grand Teton National Parks sites in Wyoming have a large number of smaller buildings. Delaware, Rhode Island, Vermont, and New Hampshire have the lowest number of civilian agency sites, buildings, and total floor space. 
Table 11. DOD Service Top Five States for Number of Sites, Buildings and Total Floor Space

\begin{tabular}{lcllll}
\hline & Rank & Air Force & \multicolumn{1}{c}{ Army } & \multicolumn{1}{c}{ ARCE } & Navy \\
\hline Sites & 1 & California & Alaska & Ohio & California \\
& 2 & Alaska & Pennsylvania & Texas & Virginia \\
& 3 & Texas & Texas & Pennsylvania & Florida \\
& 4 & New York & California & Oklahoma & Hawaii \\
& 5 & Florida & New York & Kentucky & Washington \\
\hline Buildings & 1 & California & Texas & Oklahoma & California \\
& 2 & Texas & California & Texas & Hawaii \\
& 3 & Florida & Georgia & Georgia & North Carolina \\
& 4 & New Mexico & Alabama & Kansas & Virginia \\
& 5 & Arizona & Virginia & Arkansas & Florida \\
\hline Floor Space & 1 & California & Texas & Oregon & California \\
& 2 & Texas & Georgia & Texas & Virginia \\
& 3 & Florida & California & Florida & Florida \\
& 4 & Georgia & Virginia & Georgia & North Carolina \\
& 5 & Ohio & Alabama & Louisiana & Hawaii \\
\hline
\end{tabular}

Location of Federal sites is important in terms of available incentives from either the state, or state run organizations, or utilities in terms of available incentives that can be used to offset the cost of implementing efficiency programs. Geographic location is also important in terms of baseline energy and water cost, which in important in determining the cost-effectiveness of potent specific energy and water efficiency measures. For example, in California large opportunities exist for obtaining incentive payments to offset the overall cost of programs compared to other states.

Five of the civilian agencies were selected to investigate the distribution of sites, number of buildings, and total floor space. These agencies included DOE, GSA, Health and Human Services (HHS), National Aeronautics and Space Administration (NASA), and VA. The results can be seen in Table 12. For DOE, California has the most sites (12\%), New Mexico has the most number of buildings (25\%) and Tennessee has the greatest total floor space (15\%). For GSA, New York has the most sites (11\%), Maryland has the most buildings (12\%) and Washington DC has the greatest total floor space (17\%). For HHS, Arizona has the most sites (20\%) and number of buildings (29\%), but Maryland has the greatest total floor space (41\%). NASA only has sites in 12 states. California has the most sites (42\%), number of buildings (26\%) and greatest total floor space (24\%). For the VA, New York has the most sites (7\%) and the greatest total floor space (9\%); and California has the most number of buildings (7\%). 
Table 12. Civilian Agencies Top Five States for Number of Sites, Buildings and Total Floor Space

\begin{tabular}{lllllll}
\hline & Rank & \multicolumn{1}{c}{ DOE } & \multicolumn{1}{c}{ GSA } & \multicolumn{1}{c}{ HHS } & NASA & \multicolumn{1}{c}{ VA } \\
\hline Sites & 1 & California & New York & Arizona & California & New York \\
& 2 & Colorado & Texas & New Mexico & Florida & California \\
& 3 & New Mexico & Illinois & South Dakota & $*$ & Virginia \\
& 4 & Tennessee & Washington DC & Alaska & & Pennsylvania** \\
& 5 & Ohio & Maryland & Montana & & Texas** \\
\hline Buildings & 1 & New Mexico & Maryland & Arizona & California & California \\
& 2 & California & New Jersey & South Dakota & Florida & New York \\
& 3 & Tennessee & New York & New Mexico & Virginia & Maryland \\
& 4 & Texas & Texas & Maryland & Ohio & Pennsylvania \\
& 5 & South Carolina & California & Montana & Maryland & Texas \\
\hline Floor Space & 1 & Tennessee & Washington DC & Maryland & California & New York \\
& 2 & New Mexico & California & Arizona & Florida & California \\
& 3 & Ohio & Maryland & Georgia & Maryland & Texas \\
& 4 & California & New York & New Mexico & Alabama & Illinois \\
& 5 & Kentucky & Texas & Alaska & Louisiana & Pennsylvania \\
\hline
\end{tabular}

*Louisiana, Virginia, Ohio, Mississippi, and New Mexico all tied for 3rd place

**Pennsylvania and Texas have same number of sites for VA

\subsection{Specific Agency Examples}

Federal agencies can have sub-agencies but the FSCDB only has sub-agencies broken out for four agencies - DOI, DOJ, DOT, and USDA. The sub-agency data is not included in the total agency data set. With this data, it is possible look at sub-agency data to see how it compares to the agency data. For DOI, California has the most sites ( $9 \%$ ) and floor space (15\%), but Wyoming has the most number of buildings (20\%) (Table 13). For DOI-BIA, Arizona has the most sites (20\%), number of buildings (33\%) and floor space (30\%). For DOI-Fish and Wildlife Service (DOI-FW), Washington has the most sites (11\%), Alaska has the most number of buildings (12\%) and Illinois has the greatest total floor space (19\%).

For DOJ, Texas has the most sites (22\%) and number of buildings (27\%), but Georgia has the greatest total floor space (23\%) (Table 13). For DOJ-BOP, Texas has the most sites (13\%), number of buildings (15\%) and floor space (14\%).

For DOT, California has the most sites (11\%), Massachusetts has the most number of buildings (15\%) and New York has the greatest total floor space (17\%) (Table 13). For the DOT-FAA, California has the most sites $(10 \%)$, Alaska has the most number of buildings (13\%), and Virginia has the greatest total floor space (15\%). 
Table 13. Civilian Agencies and Sub-Agencies Top Five States for Number of Sites, Buildings and Total Floor Space

\begin{tabular}{|c|c|c|c|c|c|c|c|c|c|c|c|}
\hline & Rank & $\mathrm{DOI}$ & DOI -BIA & DOI-FW & DOJ & DOJ-BOP & DOT & DOT-FAA & USDA & USDA-ARS & USDA-FS \\
\hline \multirow[t]{5}{*}{ Sites } & 1 & California & Arizona & Washington & Texas & Texas & California & California & Florida & Texas & California \\
\hline & 2 & Washington & New Mexico & Alaska & California & California & Massachusetts & Texas & California & Florida & Colorado \\
\hline & 3 & Arizona & South Dakota & California & Montana & Florida & Michigan & Alaska & Maryland & California & Oregon \\
\hline & 4 & Alaska & Alaska & Idaho & Arizona & $*$ & Florida & New York & New York & Georgia & Idaho \\
\hline & 5 & Idaho & Washington & Oregon & Minnesota & & New York & Pennsylvania & Texas & $* *$ & Utah \\
\hline \multirow[t]{5}{*}{ Buildings } & 1 & Wyoming & Arizona & Alaska & Texas & Texas & Massachusetts & Alaska & Texas & Maryland & California \\
\hline & 2 & California & New Mexico & Illinois & California & California & Florida & California & Florida & Texas & Oregon \\
\hline & 3 & Washington & South Dakota & Washington & Georgia & Pennsylvania & California & Texas & New York & Mississippi & Idaho \\
\hline & 4 & Pennsylvania & North Dakota & Arizona & Montana & Florida & New York & New Jersey & lowa & Georgia & Montana \\
\hline & 5 & Virginia & Montana & Texas & Arizona & Minnesota & Washington & Virginia & Mississippi & Florida & Colorado \\
\hline \multirow[t]{5}{*}{ Floor Space } & 1 & California & Arizona & Illinois & Georgia & Texas & New York & Virginia & Maryland & Maryland & California \\
\hline & 2 & Wyoming & New Mexico & Washington & Virginia & California & Massachusetts & New Jersey & Texas & Texas & Oregon \\
\hline & 3 & Pennsylvania & South Dakota & West Virginia & Texas & Florida & California & California & North Carolina & Georgia & Idaho \\
\hline & 4 & Washington & North Dakota & Virginia & Pennsylvania & Kentucky & Alaska & Texas & lowa & Nebraska & Montana \\
\hline & 5 & New York & Oklahoma & Maryland & California & Pennsylvania & Florida & Alaska & New York & California & Washington \\
\hline
\end{tabular}

*Illinois, Minnesota, New York, and Pennsylvania all tied for 4th place.

** Colorado, lowa, Idaho, and Oregon all tied for 5th place. 
For USDA, Florida has the most sites (10\%), Texas has the most number of buildings (15\%), and Maryland has the most floor space (25\%) (Table 13). For USDA-ARS, Texas has the most sites (9\%), and Maryland has the most number of buildings (16\%) and floor space (18\%). For USDA-FS, California has the most sites (13\%), number of buildings (16\%) and floor space (15\%). 


\subsection{Top 10 Sites}

The largest DOD and civilian agencies sites, in terms of buildings and floor space, may be drivers of energy and water consumption for that agency. By breaking out the largest installations, agencies can use this information to assist prioritize sites for the extent of efficiency improvements. The following provides information on the top ten sites for both DOD and civilian agencies.

\subsection{DOD}

When looking at the DOD data for the top ten sites for all services, the Navy has the site with the largest number of buildings (site in North Carolina), but the Army has the site with greatest total floor space (site in Texas). The Army and Navy both have four sites and the Air Force has two sites in the top 10 for total number of buildings. The Army has 6, the Navy has 3, and the Air Force has 1 site in the top 10 for total floor space.

\subsection{Civilian}

When looking at the civilian data for the top 10 sites, DOI has the site with the largest number of buildings (site in Wyoming). However, this site only ranks $26^{\text {th }}$ for total floor space. DOE and DOI each have 4 sites and DOI-BIA has 2 sites in the top 10 for total number of buildings. DOE has 7 sites and DOI$\mathrm{BIA}, \mathrm{HHS}$, and NASA each have 1 site in the top 10 for total floor space. DOE has the largest site for total floor space (site in Ohio), however, this site ranks $116^{\text {th }}$ for total number of buildings indicating the occurrence of very large individual buildings on the site. 


\subsection{Changes over Time - DOE}

Data is available for DOE building inventory for 2000 and for 2008, and this lends itself to looking at changes in an agency's real property over time. When comparing data between these 2 years, there are major changes in some of the DOE building types; however, when looking at overall changes to building counts and total floor space, the building stock has not changed considerably.

Overall, total number of buildings have decreased $8.0 \%$ and total floor space has decreased $5.1 \%$ from 2000 to 2008 (Figures 10, 11 and Tables 14, 15). When looking at specific building types by building counts, the number of buildings classified as offices has increased $62.4 \%$, while the number of buildings classified as other has increase $50 \%$. Storage building types and hospitals have decreased $28 \%$ and $25.8 \%$, respectively. Other building types have increased in total floor space $79.1 \%$ and office building types have increase in total floor space $46.2 \%$. Whereas, service $(26 \%)$ and industrial $(25.2 \%)$ building types total floor space has gone down since 2000 to 2008.

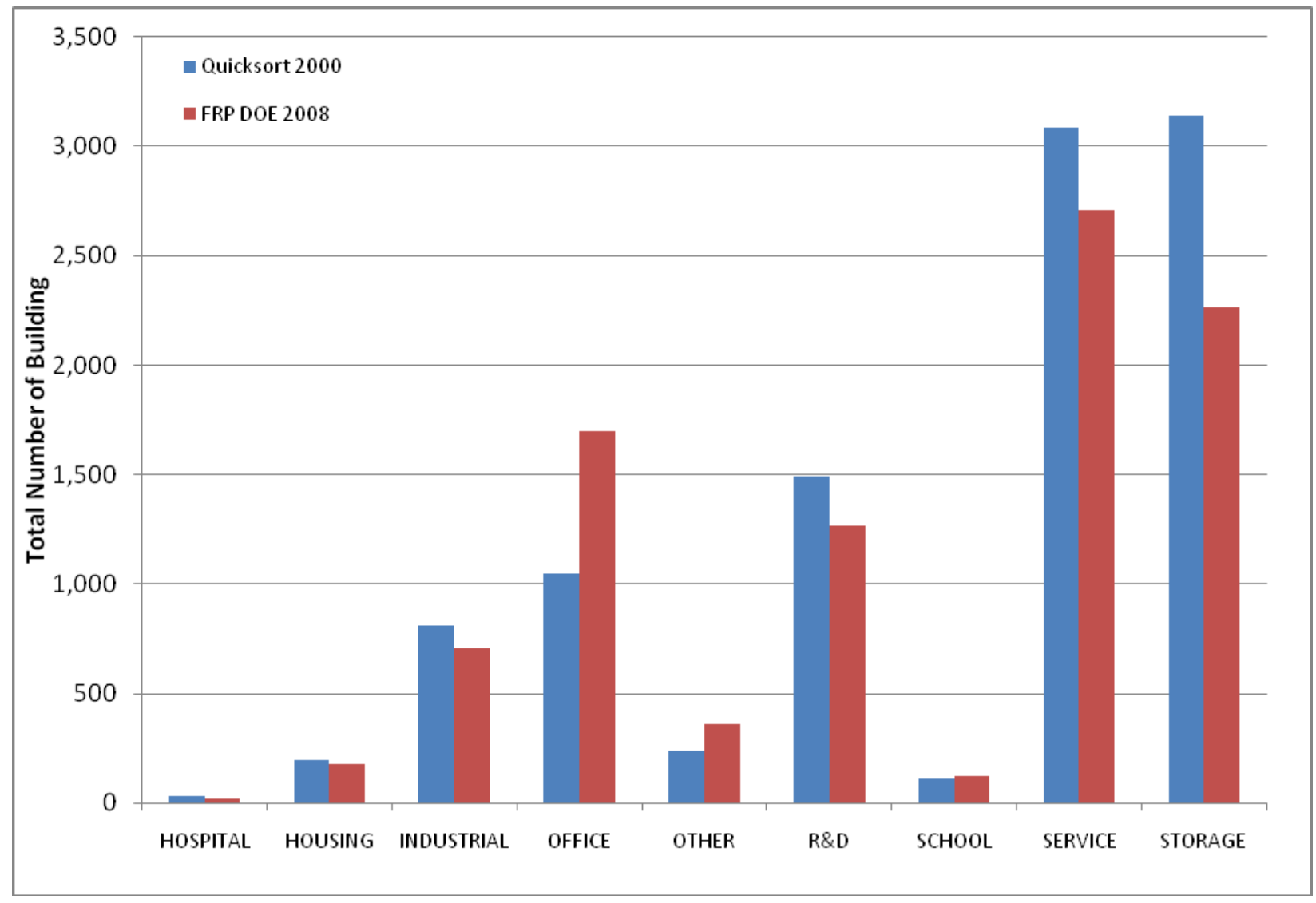

Figure 10. Changes in Total Building Counts by Building Types for DOE 


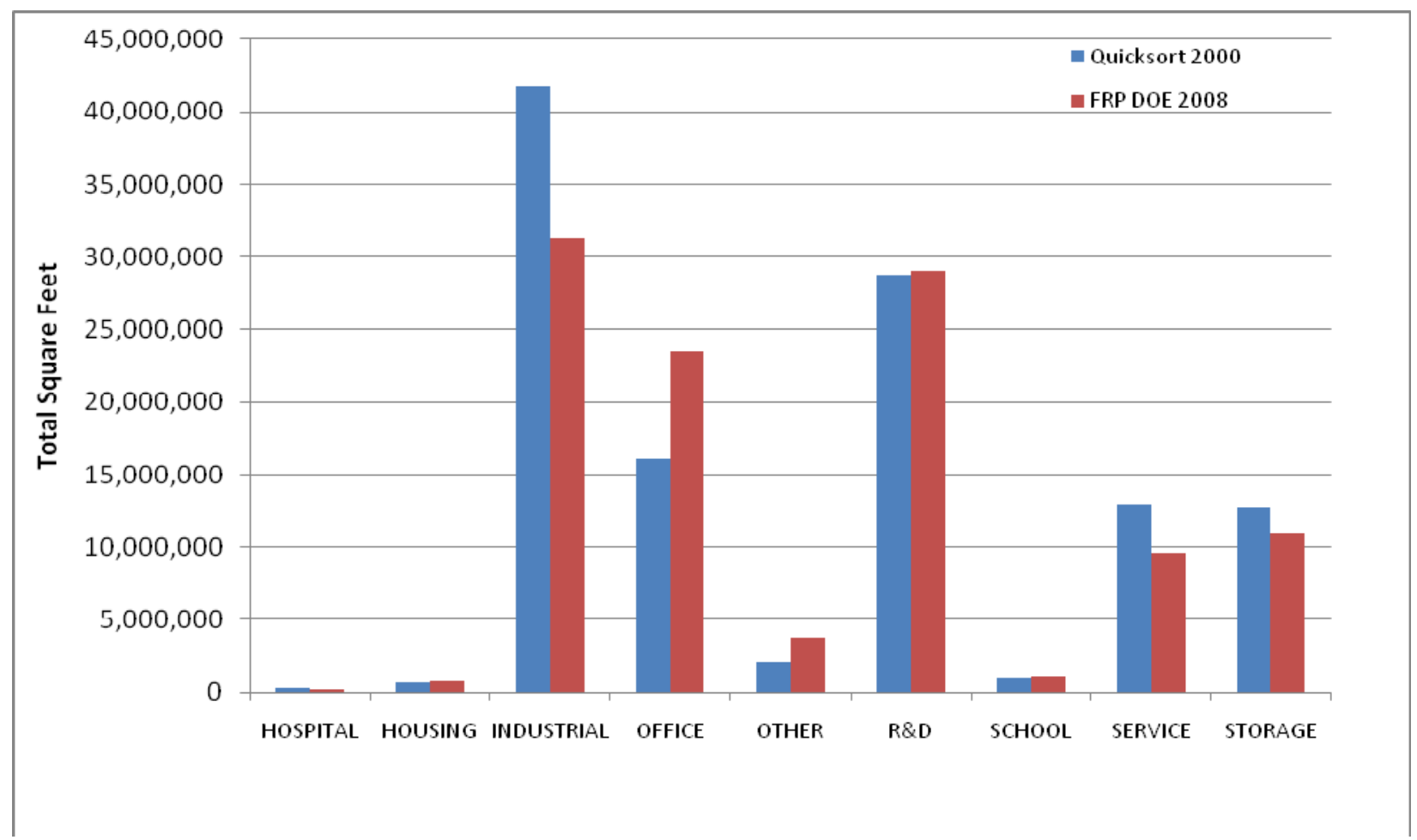

Figure 11. Changes in Total Floor Space $\left(\mathrm{ft}^{2}\right)$ by Building Types for DOE

Table 14. Changes to DOE Building Stock by Building Type and Building Count

\begin{tabular}{|c|c|c|c|c|c|c|c|c|c|c|}
\hline & \multicolumn{10}{|c|}{ Total Building Counts } \\
\hline Ouicksort & HOSPITAL & HOUSING & INDUSTRIAL & OFFICE & OTHER & $R$ and $D$ & SCHOOL & SERVICE & STORAGE & TOTAL \\
\hline $\begin{array}{l}2000 \\
\text { FRP DOE }\end{array}$ & 31 & 199 & 811 & 1,046 & 242 & 1,491 & 110 & 3,082 & 3,139 & 10,151 \\
\hline 2008 & 23 & 181 & 710 & 1,699 & 363 & 1,264 & 124 & 2,710 & 2,261 & 9,335 \\
\hline Percent & & & & & & & & & & \\
\hline Change & $-25.8 \%$ & $-9.0 \%$ & $-12.5 \%$ & $62.4 \%$ & $50.0 \%$ & $-15.2 \%$ & $12.7 \%$ & $-12.1 \%$ & $-28.0 \%$ & $-8.0 \%$ \\
\hline
\end{tabular}


Table 15. Changes to DOE Building Stock by Building Type and Total Floor Space

\begin{tabular}{|c|c|c|c|c|c|c|c|c|c|c|}
\hline & \multicolumn{10}{|c|}{ Total Floor Space $\left(\mathrm{ft}^{2}\right)$} \\
\hline & HOSPITAL & HOUSING & INDUSTRIAL & OFFICE & OTHER & R\&D & SCHOOL & SERVICE & STORAGE & TOTAL \\
\hline Quicksort & & & & & & & & & & \\
\hline 2000 & 258,306 & 694,843 & $41,769,500$ & $16,094,741$ & $2,121,897$ & $28,720,333$ & 943,436 & $12,966,260$ & $12,733,133$ & $116,302,449$ \\
\hline FRP DOE & & & & & & & $1,082,0$ & & & \\
\hline 2008 & 223,033 & 790,205 & $31,263,936$ & $23,533,437$ & $3,800,863$ & $29,057,566$ & 66 & $9,593,910$ & $10,997,724$ & $110,342,740$ \\
\hline Percent & & & & & & & & & & \\
\hline Change & $-13.7 \%$ & $13.7 \%$ & $-25.2 \%$ & $46.2 \%$ & $79.1 \%$ & $1.2 \%$ & $14.7 \%$ & $-26.0 \%$ & $-13.6 \%$ & $-5.1 \%$ \\
\hline
\end{tabular}

The building categories of office, other, and school have not only increased in total number of buildings but in total floor space as well. Hospitals, industrial, service and storage building types have decreased in both number of buildings and total floor space. Housing and R \& D have decreased in building count, but total floor space has increased. The exact reason for these changes is unknown, but a few factors may be involved. Buildings may have been recategorized to a different building type. Older buildings are not being used and/or newer buildings with different building types are being built.

Changes in inventory can be useful to an agency to assist in understanding the influences on energy and water intensity. As building stock changes, so does the agency's water and energy consumption. In the case of DOE, there has been a large upswing in office space and a reduction in industrial buildings. Industrial buildings tend to be much more energy and water intensive than office buildings. So as DOE's building stock trends to less resource intensive buildings, the agency may experience an overall energy and water intensity reduction. 


\subsection{Conclusion}

Federal laws and Executive Orders require Federal agencies to reduce energy use, pollution, and water and fuel consumption, and report progress in meeting these goals on an annual basis. Energy and water saving opportunities can be identified using the building characteristics information provided by the FEMP database. The database allows Federal agencies to identify the location and type of potential projects, once implemented, will increase the energy efficiencies and/or water conservation of the sites thus achieving mandated goals for the agency and saving taxpayer dollars. All aspects of the Federal building stock, such as the geographic location of Federal sites, along with building types, building counts, total floor space and changes over time should be considered when identifying efficiency potentials. To isolate one aspect of the Federal building stock does not provide a full, realistic picture. 


\subsection{References}

EISA 2007. Energy Security and Independence Act of 2007. Public Law 110-140.

72 FR 3919 - 3923. January 26, 2007. “Executive Order 13423 - Strengthening Federal Environmental, Energy, and Transportation Management. "Federal Register, The President.

74 FR 52117 - 52127. October 8, 2009. "Executive Order 13514 - Federal Leadership in Environmental, Energy, and Economic Performance." Federal Register, The President.

The Federal Real Property Council (FRPC). 2009. FY 2008 Federal Real Property Report; An Overview of the U.S. Federal Government's Real Property Assets. Published by GSA Office of Government Wide Policy.

Drexel University. 2009. ipl2 - This website is a merger of Internet Public Library (IPL) and Librarians' Internet Index (LII). Accessed 15 September 2010,

<http://www.ipl.org/div/stateknow/popchart.html\#statesbyland>. 